\title{
WestVirginiaUniversity
}

THE RESEARCH REPOSITORY @ WVU

Graduate Theses, Dissertations, and Problem Reports

2012

\section{Synthesis of Benzofluorenyl Derivatives Bearing Thiophene Substituents}

Doreen Makaya

West Virginia University

Follow this and additional works at: https://researchrepository.wvu.edu/etd

\section{Recommended Citation}

Makaya, Doreen, "Synthesis of Benzofluorenyl Derivatives Bearing Thiophene Substituents" (2012).

Graduate Theses, Dissertations, and Problem Reports. 4892.

https://researchrepository.wvu.edu/etd/4892

This Thesis is protected by copyright and/or related rights. It has been brought to you by the The Research Repository @ WVU with permission from the rights-holder(s). You are free to use this Thesis in any way that is permitted by the copyright and related rights legislation that applies to your use. For other uses you must obtain permission from the rights-holder(s) directly, unless additional rights are indicated by a Creative Commons license in the record and/ or on the work itself. This Thesis has been accepted for inclusion in WVU Graduate Theses, Dissertations, and Problem Reports collection by an authorized administrator of The Research Repository @ WVU. For more information, please contact researchrepository@mail.wvu.edu. 
Synthesis of Benzofluorenyl Derivatives Bearing Thiophene Substituents

DOREEN MAKAYA

Thesis submitted to the

Eberly College of Arts and Sciences

At West Virginia University

in partial fulfillment of the requirements

for the degree of

Master of Science

in

Chemistry

Kung K. Wang, Ph.D., Chair

Jeffrey L. Petersen, Ph.D.

Björn C.G. Söderberg, Ph.D.

C. Eugene Bennett Department of Chemistry

Morgantown, West Virginia

2012

Keywords: Benzannulated enyne-allene, thiophene 


\section{ABSTRACT \\ Synthesis of Benzofluorenyl Derivatives Bearing Thiophene Substituents \\ Doreen Makaya}

A four-step synthetic sequence was used to prepare 10-(1,1-dimethylethyl)-5-thienyl$11 H$-benzo $[b]$ fluorene from pivalophenone. The key step of the synthetic sequence involved the Schmittel cascade cyclization reaction of the corresponding benzannulated enyne-allene having a thienyl substituent at the alkynyl terminus. The benzannulated enyne-allene was prepared by an initial condensation of pivalophenone with the lithium acetylide derived from 2iodophenylethyne to form 3-(2-iodophenyl)-1-(1,1-dimethylethyl)-1-phenyl-2-propyn-1-ol. Reduction of the propagylic alcohol with triethylsilane in the presence of trifluoroacetic acid then furnished 1-(1,1-iodophenyl)-3-(1,1-dimethylethyl)-3-phenyl-1-propyne. The Sonogashira reaction with 2-ethynylthiophene then produced the corresponding 10-(1,1-dimethylethyl)-5thienyl-11H-benzo[b]fluorene from pivalophenone. Similarly, starting from benzophenone, 10phenyl-5-thienyl-11 $H$-benzo[b]fluorene was obtained.

The X-ray crystallographic structure of 10-(1,1-dimethylethyl)-5-thienyl-11 $\mathrm{H}$ benzo $[b]$ fluorene shows that the thienyl substituent has a perpendicular orientation relative to the backbone of the benzofluorenyl system. As a result, the hydrogen atom on carbon- 4 is in the magnetically shielded region of the thienyl ring current and thus shows an upfield-shifted signal at $\delta 6.45$.

The successful Sonogashira reaction between 2,6-bis[(4R)-4,5-dihydro-4-phenyl-2oxazolyl]-4-ethynylpyridine and iodobenzene is a promising way of making benzannulated enediynes bearing pyridine-2,6-bisoxazoline (pybox) ligands at the acetylenic position leading to benzofluorenyl systems possessing pybox moieties. Such heteroaromatic compounds are potentially useful for enantioselective reactions and for asymmetric catalysis. 


\section{Dedicated to}

my daughters Sithokozile and Christaan 


\section{ACKNOWLEDGEMENT}

My utmost gratitude and appreciation goes to my research advisor, Dr. Kung. K. Wang for his advice, encouragement and kindness during the course of my research and in compilation of my thesis. Special thanks is due to my research committee members, Dr. Jeffrey L. Petersen and Dr. Björn C. G. Söderberg for their constructive comments and suggestions. Further appreciation is extended to Dr. Jeffrey L. Petersen for his help with X-ray structure analysis of my compounds.

I also wish to thank my daughters, Sithokozile and Christaan for their understanding, encouragement, happiness and joy. Many thanks go to my parents for their support. Above all, I thank my friend Barbara Linn for her helpful assistance in supporting my dreams and aspirations.

For financial support, I thank the C. Eugene Bennett Department of Chemistry and the National Science Foundation. 


\section{TABLE OF CONTENTS}

Title page

$\begin{array}{ll}\text { Abstract } & \text { ii }\end{array}$

Dedication iv

Acknowledgements $\quad$ v

Table of Contents

List of Figures

$\begin{array}{ll}\text { Appendix } & \text { vii }\end{array}$

Approval of Examining Committee ix

$\begin{array}{lr}\text { 1. Introduction } & 1\end{array}$

$\begin{array}{lr}\text { 2. Results and Discussion } & 8\end{array}$

2.1 Development of a Synthetic route for 10-(1,1-dimethylethyl)-5-thienyl$11 H$-benzo $[b]$ fluorene 29

2.2 Development of a Synthetic route for Synthesis of 10-phenyl-5-thienyl-11H$\begin{array}{lr}\text { benzo }[b] \text { fluorene } 30 & 10\end{array}$

2.3 Development of a Synthetic route for benzannulated enediynyl alcohol $47 \quad 12$

$\begin{array}{lc}\text { 3. Conclusion } & 13\end{array}$

$\begin{array}{ll}\text { EXPERIMENTAL SECTION } & 14\end{array}$

$\begin{array}{lc}\text { REFERENCES } & 22\end{array}$

LIST OF FIGURES

Figure 1. Structures of an oxazoline system and benzofluorenyl systems bearing thienyl Substituents

Figure 2. ORTEP drawing of the crystal structure of 10-(1,1-dimethylethyl)-5-thienyl- 
Appendix $\left({ }^{1} \mathrm{H}\right.$ NMR and ${ }^{13} \mathrm{C}$ NMR Spectra)

${ }^{1}$ H NMR spectra of propagylic alcohol 34

${ }^{13} \mathrm{C}$ NMR Spectra of spectra of propagylic alcohol 34

${ }^{1}$ H NMR spectra of 1-iodo-2-(4,4-dimethyl-3-phenyl-1-pentnyl)benzene

${ }^{13} \mathrm{C}$ NMR spectra of 1-iodo-2-(4,4-dimethyl-3-phenyl-1-pentnyl)benzene

${ }^{1} \mathrm{H}$ NMR spectra of benzannulated enediyne 37

${ }^{13} \mathrm{C}$ NMR spectra of benzannulated enediyne 37

${ }^{1} \mathrm{H}$ NMR spectra of 10-(1,1-dimethylethyl)-5-thienyl-11 $H$-benzo[b]fluorene 29

${ }^{13} \mathrm{C}$ NMR Spectra of 10-(1,1-dimethylethyl)-5-thienyl-11 $H$-benzo[b]fluorene 29

${ }^{1} \mathrm{H}$ NMR spectra of propagylic alcohol 40

${ }^{13} \mathrm{C}$ NMR Spectra of propagylic alcohol $\mathbf{4 0}$

${ }^{1} \mathrm{H}$ NMR spectra of 1-iodo-2-(3,3-diphenyl-1-propynyl)benzene 41

${ }^{13} \mathrm{C}$ NMR Spectra of 1-iodo-2-(3,3-diphenyl-1-propynyl)benzene 41

${ }^{1}$ H NMR spectra of 10-phenyl-5-thienyl-1 $1 H$-benzo[b]fluorene 30

${ }^{13} \mathrm{C}$ NMR Spectra of 10-phenyl-5-thienyl-11 $H$-benzo[b]fluorene 30

${ }^{1}$ H NMR spectra of propagylic alcohol 45

${ }^{13} \mathrm{C}$ NMR Spectra of propagylic alcohol 45

${ }^{1}$ H NMR spectra of benzannulated enediynyl alcohol 47 
${ }^{13} \mathrm{C}$ NMR Spectra of benzannulated enediynyl alcohol $\mathbf{4 7}$

${ }^{1} \mathrm{H}$ NMR spectra of the derivative of the pybox ligand 32

${ }^{13} \mathrm{C}$ NMR Spectra of the derivative of the pybox ligand $\mathbf{3 2}$ 


\section{INTRODUCTION}

Over the past few decades, thiophene chemistry has been intensively investigated and many interesting applications have been discovered. Considerable attention has been given to the unique physical and chemical properties of thiophene compounds, notably their outstanding electronic, optical, redox, ${ }^{1}$ charge transport and self-assembly properties. ${ }^{2,3}$ Self-assembly is a versatile tool in constructing supramolecular organization of pi-conjugated molecules by formation of non-covalent bonds. ${ }^{4}$ Pi-conjugation of polymer backbones increases the intermolecular interactions resulting in rigid structures. Thiophene rings have highly polarizable sulfur atoms which stabilize conjugated chains and provides exceptional charge transport properties. These self-organizing properties ${ }^{5,6}$ are vital in manipulating new compounds for organic electronics. ${ }^{7}$ Conjugate polymers can be structurally tailored to synthesize new electronic compounds by varying the position and character of side chains and the types of functional groups. These variations may affect solubility, ionic conductivity, band gap, morphology and miscibility. ${ }^{8}$

Structural variations of thiophene present great potential in tuning of their electrical properties. ${ }^{6}$ Numerous methods have now been developed to modify thiophene systems. Conducting polymers have turned out to be of intense interest because of their favorable technological applications especially in the construction of electrochromic devices. ${ }^{9,10}$ Conducting thiophene compounds are structurally versatile and easier to synthesize for solid state applications than inorganic materials. ${ }^{11}$

Our research group has reported several synthetic routes using benzanulated enyneallenes to form benzofluorenes via the Schmittel cyclization reactions. The reaction is also 
applicable to systems bearing nitrogen as a heteroatom. Intrigued by the vast applications of compounds bearing thiophene moieties, we envisioned that the chemistry developed in our group for making benzofluorenes could also provide opportunities to incorporate thiophenes in the aromatic systems.

Understanding the mechanisms of the Schmittel cyclization reactions is pivotal in designing new synthetic methods for these aromatization reactions. Enyne-allenes will follow either the Myers-Saito (C2-C7) ${ }^{12}$ pathway or the C2-C6 (Schmittel) ${ }^{13}$ pathway depending on the substitution at the allenic or acetylenic terminus (Scheme 1). ${ }^{14}$ Both steric and electronic effects play a role in determining whether a reaction will undergo the Schmittel or the Myers-Saito pathway. If R1 and R2 are sterically demanding, biradical 2 is not formed because steric interactions of the two groups will prevent it from forming. Instead, in the case where R2 is a sterically demanding tert-butyl or a trimethylsilyl group, the Schmittel cyclization reaction to form biradical 3 is favored. ${ }^{15}$
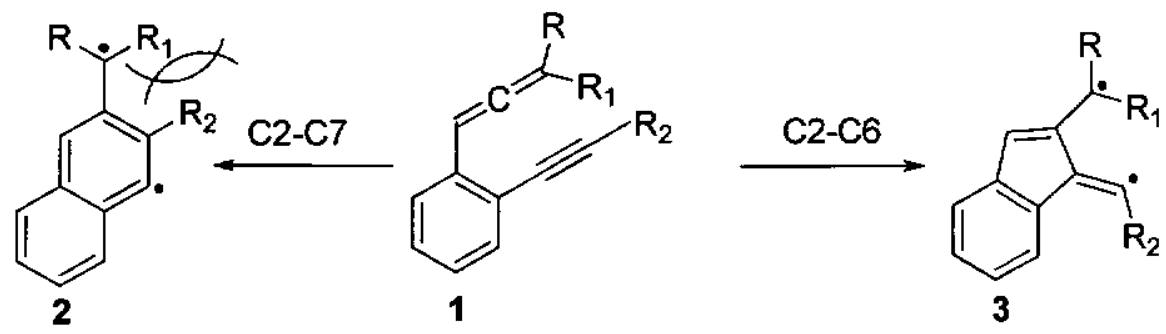

Scheme 1. Saito-Myers cyclization (2) and Schmittel cyclization (3)

If the R2 group is a hydrogen atom or a sterically non-demanding alkyl group, the MyersSaito cyclization reaction is favored. This is due, in part, to the aromaticity gained when biradical 2 is formed. ${ }^{16}$ 
Electronic effects come into play when an aryl substituent occupies the acetylenic position because it stabilizes the alkenyl radical site in 5 (Scheme 2). A phenyl substituent at the allenic terminus allows the radical-radical coupling to occur, producing the formal Diels-Alder adduct 6. Although the formation of the intermediate 6 from 4 can be viewed as a concerted Diels-Alder reaction, mechanistic studies indicate a step-wise route leading to the formation of 6 via the benzofulvenyl biradical 5. A 1,5-prototropic rearrangement of the intermediate 6 results in generation of the benzofluorene system 7 .
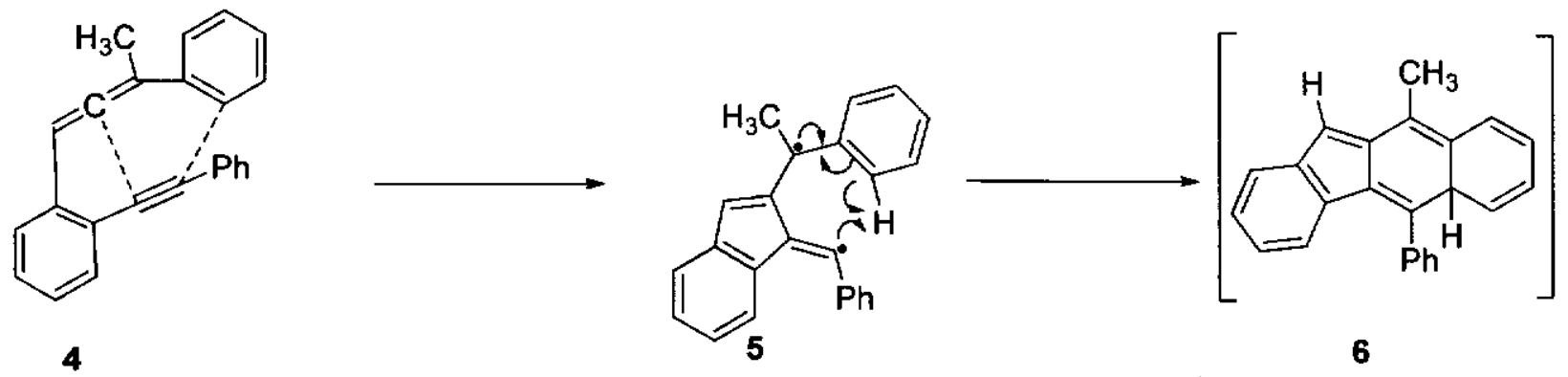

1,5-H shift

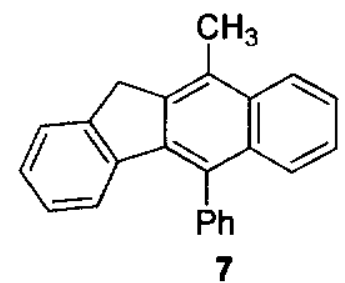

Scheme 2. Preparation of 11-H-benzo[b]fluorene 7

Our research group has developed a variety of synthetic methods for benzannulated enyne-allenes bearing a phenyl substituent at the acetylenic and allenic termini leading to benzofluorenyl derivatives.

One of the methods involved condensation between a ketone, such as $\mathbf{8}$, and a lithiated benzannulated endiyne such as $\mathbf{9}$, to form a propagylic alcohol as depicted in $\mathbf{1 0}$ (Scheme 3 ). ${ }^{17}$ Reduction of the propagylic alcohol with triethylsilane in the presence of trifluoroacetic acid led 
to the reduced adduct 11. On treatment with potassium tert-butoxide and tert-butyl alcohol, 11 was converted, in situ, to the benzannulated enyne-allene 12, which then underwent the Schmittel cyclization reaction through 13 to form 14. A 1,5-prototropic rearrangement to regain aromaticity then afforded $11-H$-benzo[ $b]$ fluorene $15{ }^{18-22}$

8

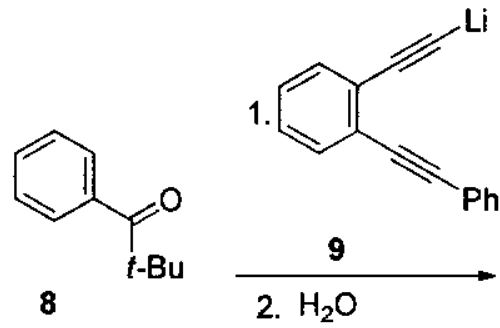<smiles>CC(C)(C)c1ccccc1C#CC(O)(C#Cc1ccccc1)c1ccccc1</smiles>

10

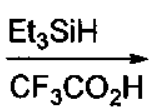<smiles>C(#Cc1ccccc1C#Cc1ccccc1)c1ccccc1</smiles>

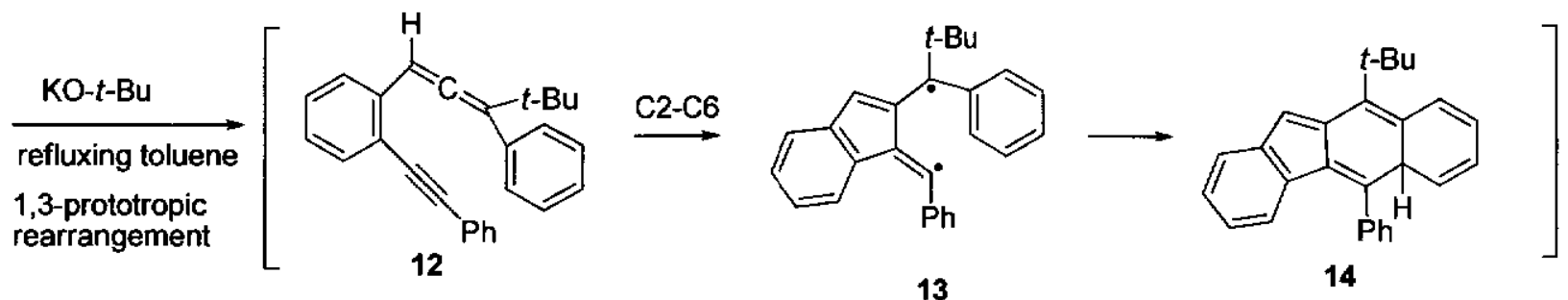

\section{1,5-prototropic rearrangement}<smiles>CC(C)(C)c1c2c(c(-c3ccccc3)c3ccccc13)-c1ccccc1C2</smiles>

15

Scheme 3. Mechanism for formation of 15

Placing a pyridine group as the heteroaromatic substituent at the allenic terminus of the enyne-allene system led to a benzofluorene system bearing a pyridine moiety. This synthetic strategy again utilized the 1,3-prototropic rearrangement to form the allenic moiety.

Apart from using potassium tert-butoxide and tert-butyl alcohol as a way of making benzannulated enyne-allenes, our research group has also utilized triethylamine and ethanol to 
effect such transformations. The pyridinium methanesulfonate 16 gave enyne-allene 17 after treatment with triethylamine in refluxing ethanol (Scheme 4). ${ }^{23}$ Similarly to what has been described about the mechanism for the formation of benzofluorenyl systems, enyne-allene 17 underwent a $\mathrm{C} 2-\mathrm{C} 6$ cyclization reaction to form biradical 18 by the Schmittel cyclization pathway. Radical-radical coupling of 18 to afford 19 was followed by prototropic rearrangement to produce the fused quilizinium methanesulfonate 20. This reaction demonstrates another approach, leading to the generation of benzofulvene biradical 18, using the Schmittel protocol to form benzofluorenyl systems with pyridine as a heteroaromatic substituent at the allenic terminus. Similar transformations of pyridine systems to enyne- allenes using tert-butoxide, for example, and tert-butyl alcohol have also been successfully demonstrated.
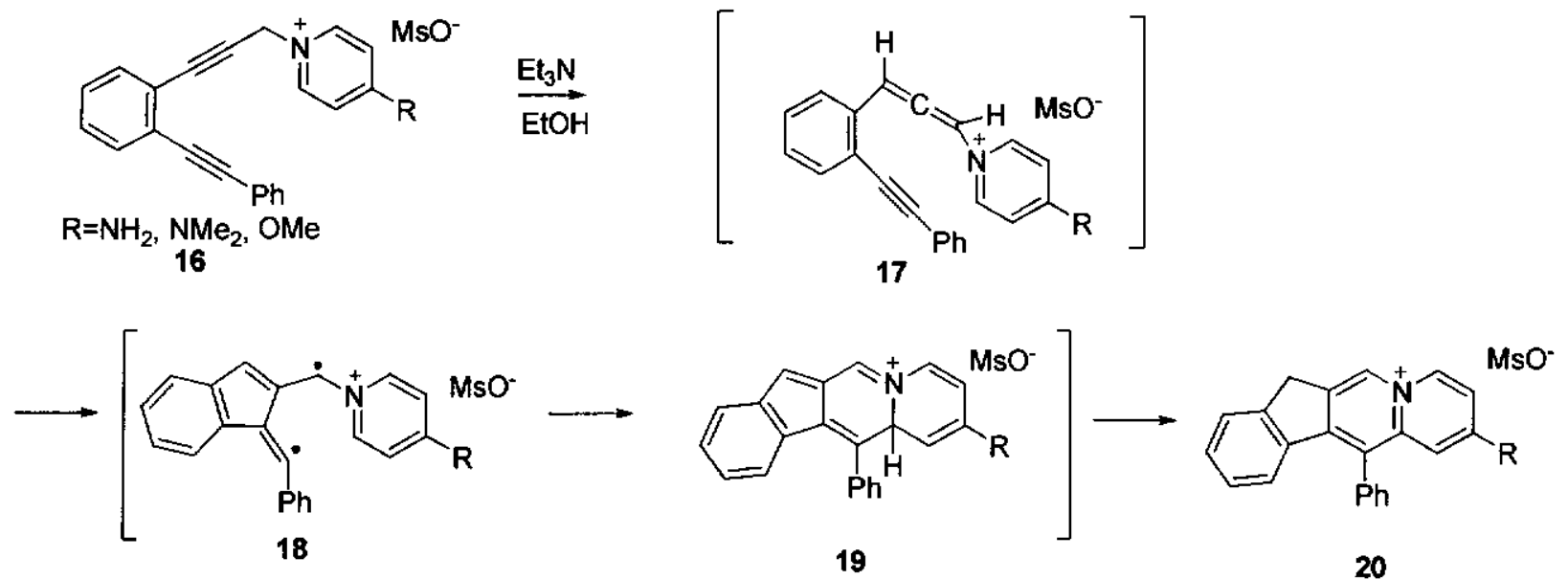

Scheme 4. Preparation of quilizinium methanesulfonate 20

The Schmittel cyclization reaction has been extended to the synthesis of compounds with helical twists. Our research group has successfully applied the Schmittel cyclization reaction to 
synthesize benzannulated enyne-allene systems with a pyridine substituent at the acetylenic terminus (Scheme 5). ${ }^{24}$

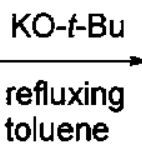

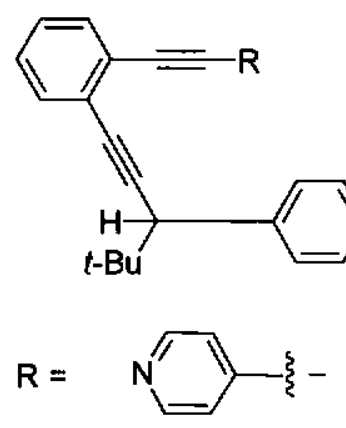

21
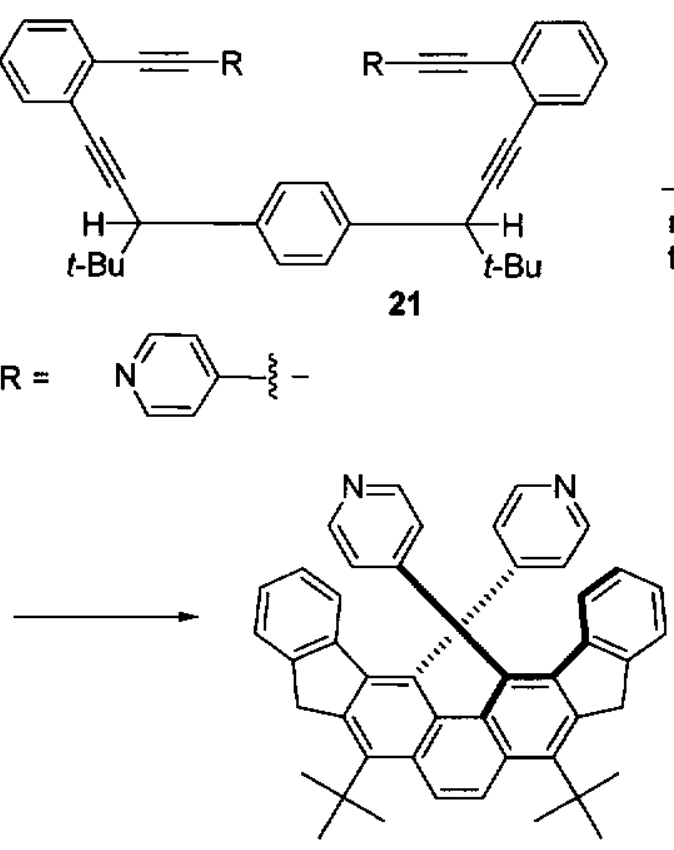

23

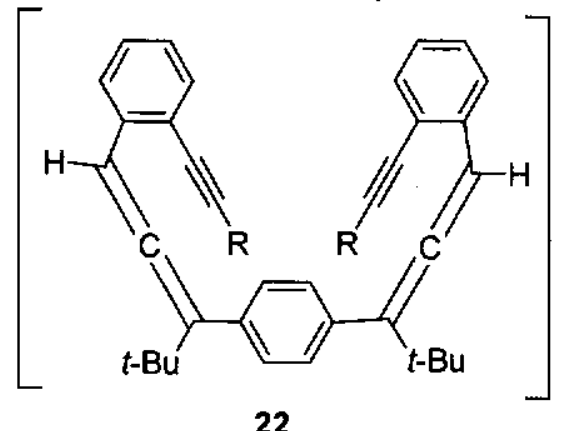

22

\section{Scheme 5. Formation of benzofluorene 23}

In addition to synthesizing enyne-allenes bearing thiophene moieties, attempts to apply a similar synthetic route in synthesizing enyne-allenes bearing pyridine-2,6-bisoxazolines, pybox ${ }^{25}$ as a substituent were also made. Our research group has successfully applied the Schmittel cyclization reactions for synthesis of benzofluorenyl systems bearing terpyridine ligands as substituents. We envisioned that a similar chemistry could be applied in making benzofluorenyl systems bearing pybox ligands as substituents. Pybox ligands contain two oxazolines and a pyridine ring. Pybox ligands are versatile compounds due to the wide variety of asymmetric catalysis reactions they offer. ${ }^{26}$ 
Various methods for the synthesis of pybox ligands have been reported by many groups. The synthetic route for making pybox 28 is outlined in Scheme $6 .{ }^{27}$ This method involves heating a mixture of one equivalent of chelidamic acid (24) and nine equivalents of phosphorus pentabromide at $90{ }^{\circ} \mathrm{C}$ for 3 hours. The product obtained was treated with methanol at $0{ }^{\circ} \mathrm{C}$ to generate dimethyl 4-bromopyridine-2,6-dicarboxylate (25). (R)-Phenylglycinol (26) was then mixed with 25 and heated at $120{ }^{\circ} \mathrm{C}$ for 16 hours to give diamide 27. para-Toluenesulfonyl chloride (TsCl) was mixed with 28 and refluxed with triethylamine for 24 hours to yield the pybox ligand 28.<smiles>COC(=O)c1cc(Br)cc(C(=O)OC)n1</smiles><smiles>N[C@@H](CO)c1ccccc1</smiles><smiles>O=C(N[C@H](CO)c1ccccc1)c1cc(Br)cc(C(=O)N[C@@H](CO)c2ccccc2)n1</smiles><smiles>Brc1cc(C2=NC(c3ccccc3)CO2)nc(C2=NC(c3ccccc3)CO2)c1</smiles>

Scheme 6. Formation of pybox ligand 28

In this project, the $\mathrm{C} 2-\mathrm{C} 6$ cyclization synthetic sequence also found success in the synthesis of 29 and $\mathbf{3 0}$ shown in Figure 1. However, attempts to synthesize $\mathbf{3 1}$ containing two thiophene units were unsuccessful. Preliminary studies using $\mathbf{3 2}$ as a model to try to introduce the heterocyclic pyridine bisoxazoline onto the benzofluorenyl system were conducted. 


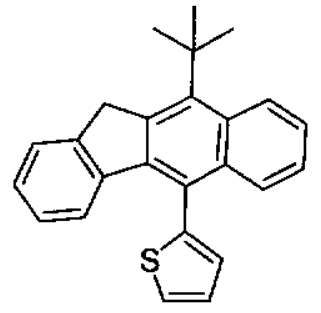

29

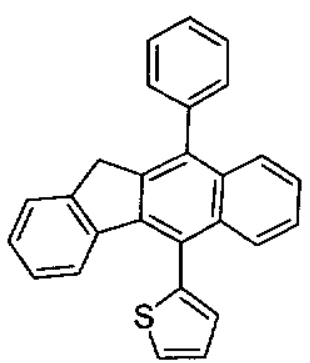

30

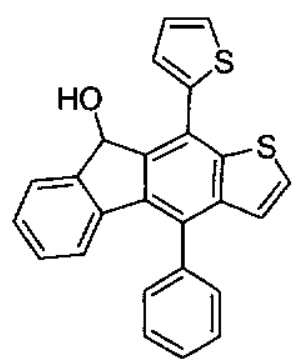

31 not formed

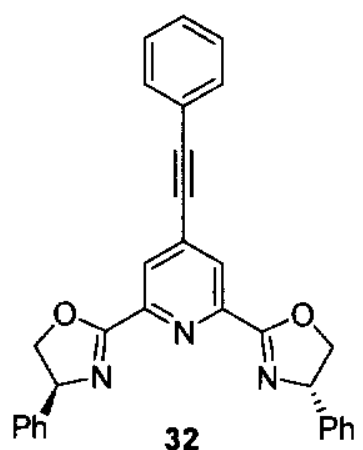

32

Figure 1. Structures of an oxazoline system and benzofluorenyl systems bearing thienyl substituents.

\section{RESULTS AND DISCUSSION}

\subsection{Development of a synthetic route for 29}

Benzofluorenes 29 and 30 contain a thiophene group at the C5 position of the benzofluorenyl system. The synthetic sequence outlined in Scheme 7 for 29 involved condensation of $\mathbf{8}$ and one equivalent of the lithium acetylide of $\mathbf{3 3}$ to afford alcohol $\mathbf{3 4}$ in excellent yield. Reduction of $\mathbf{3 4}$ with triethylsilane in the presence trifluoroacetic acid furnished 35. Treatment of $\mathbf{3 6}$ with potassium hydroxide in the presence of methanol and water allowed an efficient in-situ generation of 2-ethynylthiophene. The subsequent Sonogashira coupling of 2ethynylthiophene with $\mathbf{3 5}$ produced $\mathbf{3 7}$. Exposure of $\mathbf{3 7}$ to potassium tert-butoxide in refluxing toluene for 6 hours promoted a prototropic rearrangement to form, in situ, the corresponding benzannulated enyne-allene 38, which in turn underwent the cascade Schmittel cyclization reaction leading to benzo $[b]$ fluorene 29 in $81 \%$ yield.

The ${ }^{1} \mathrm{H}$ NMR spectrum of 29 in $\mathrm{CDCl}_{3}$ showed a singlet at $\delta 4.51$ attributable to the methylene hydrogens on the five-membered ring of the benzofluorenyl system. The upfield shifted aromatic hydrogen at the C5 position indicates that the thiophene substituent is oriented 
perpendicular to the benzofluorenyl system. As a result, the hydrogen on the $\mathrm{C} 5$ position is located in the magnetically shielded region of the thiophene ring current, causing an upfield shift. The ${ }^{1} \mathrm{H}$ NMR analysis of the thienyl hydrogens showed that their $\delta$ values are 7.62 ( $\mathrm{dd}, \mathrm{J}=5.2$, $1.0 \mathrm{~Hz}$ ), 7.37 (multiplet) and 7.10 (multiplet).

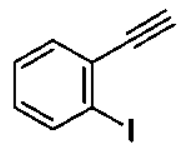

33
1. LDA

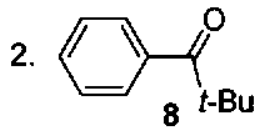

3. $\mathrm{H}_{2} \mathrm{O}$<smiles>CC(C)(C)C(O)(C#Cc1ccccc1I)c1ccccc1</smiles>

$34,97 \%$

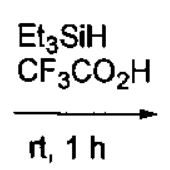

$\mathrm{rt}, \mathrm{h}$

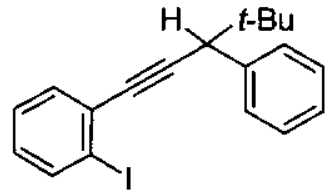

$35,93 \%$

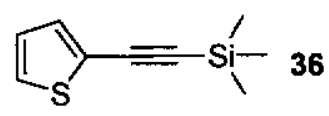

1. $\mathrm{KOH}, \mathrm{MeOH}, \mathrm{H}_{2} \mathrm{O}$

2. $\mathrm{Pd}\left(\mathrm{PPh}_{3}\right)_{2} \mathrm{Cl}_{2}$, Cul, $i-\mathrm{Pr}_{2} \mathrm{NH}$

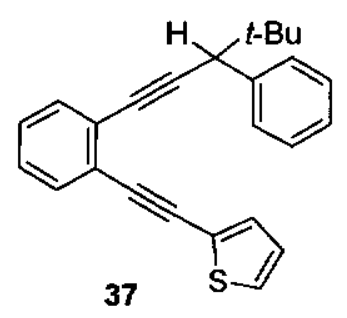

37

$\delta 4.51$

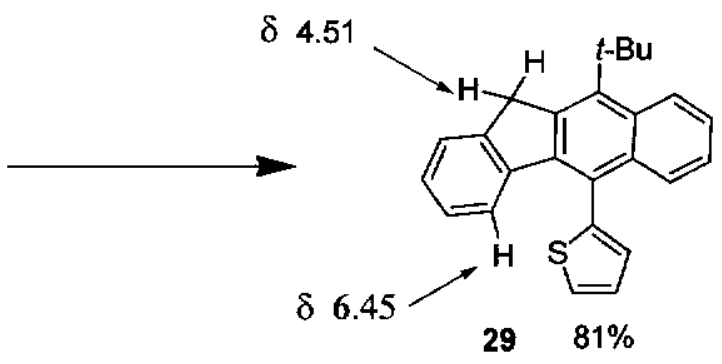

$29 \quad 81 \%$
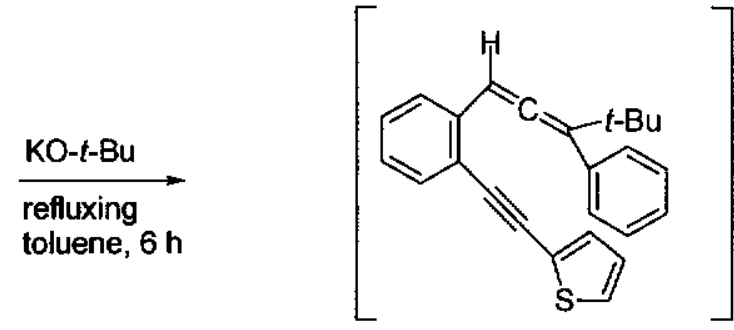

38

Scheme 7. Synthesis of benzofluorene 29

The structure of 29 was established by X-ray structure analysis. The ORTEP drawing of the crystal structure of $\mathbf{2 9}$ is given in Figure 2. The crystallographic asymmetric unit contains two independent molecules of $\mathrm{C}_{25} \mathrm{H}_{22} \mathrm{~S}$. The planar five-membered thiophene ring containing atoms $\mathrm{C}(43), \mathrm{C}(44), \mathrm{C}(43), \mathrm{C}(46)$, and $\mathrm{S}(2)$ suffers from two-site rotational disorder. The $\mathrm{X}$-ray 
structure also shows that the thiophene unit is oriented essentially perpendicular to the benzofluorenyl system, placing the hydrogen on the $\mathrm{C} 4$ carbon in the magnetically shielded region of the thiophene ring current as indicated in the ${ }^{1} \mathrm{H}$ NMR spectrum.

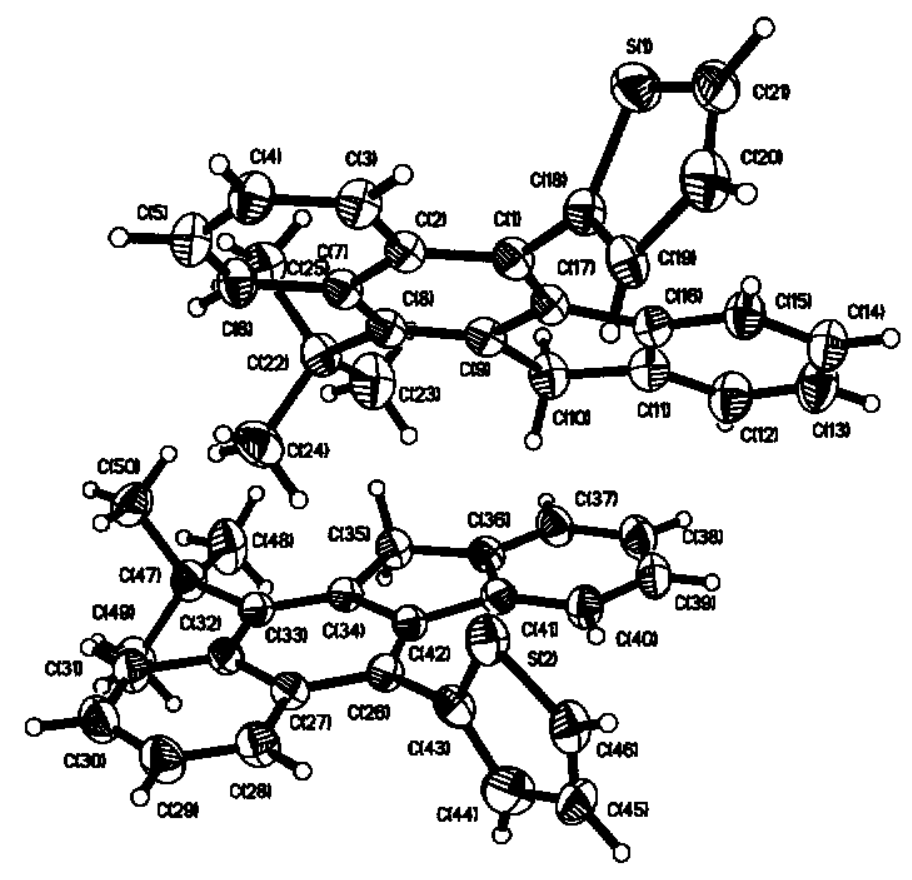

Figure 2. ORTEP drawing of the crystal structure of 29 containing two independent molecules. The thermal ellipsoids are scaled to enclose $30 \%$ probability.

1.2. Development of a synthetic route for $\mathbf{3 0}$. The synthetic sequence leading to $\mathbf{3 0}$ involved reaction of 1-ethynyl-2-iodobenzene (33) with lithium diisopropylamide to generate the corresponding lithium acetylide followed by condensation with benzophenone (39) to produce propagylic alcohol 40 (Scheme 8). Subsequent reduction of $\mathbf{4 0}$ with triethylsilane in the presence of trifluoroacetic acid afforded 41. An in-situ generation of 2-ethynylthiophene from 36 occurred after treatment with potassium hydroxide in the presence of methanol and water as described 
earlier for the synthesis of 29. The subsequent Sonogashira coupling reaction of 41 with 2ethynylthiophene at room temperature for 24 hours produced $\mathbf{3 0}$ in a single operation. An initial formation of 42, which in the presence of potassium hydroxide was transformed to the benzannulated enyne-allene 43 , occurred at room temperature. The subsequent Schmittel cyclization reaction then led to 30 . The ${ }^{1} \mathrm{H}$ NMR spectrum of 30 in $\mathrm{CDCl}_{3}$ showed a singlet at $\delta$ 3.87 which is indicative of the methylene hydrogens on the five-membered ring of the benzofluorenyl molecule. Again, the hydrogen at the $\mathrm{C} 4$ position, which experiences the shielding effect of the thienyl group appears at $\delta 6.68$. The observation of a relatively broad aromatic hydrogen signal at $\delta 7.47$ suggests that the rates of rotations around the $\mathrm{C}-\mathrm{C}$ bonds attaching to the phenyl and the thiophene groups to the benzofluorenyl system are relatively slow on the NMR scale. As a result, the ${ }^{\mathrm{l}} \mathrm{H}$ NMR signal of the ortho hydrogens on the phenyl substituents is broadened. 


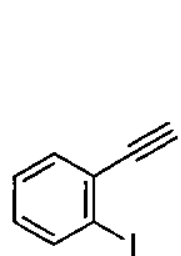

33<smiles>O=C(c1ccccc1)c1ccccc1</smiles>

3. $\mathrm{H}_{2} \mathrm{O}$<smiles></smiles>

$40,98 \%$

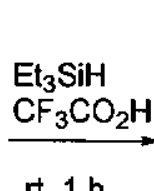

$\mathrm{rt}, 1 \mathrm{~h}$<smiles>Ic1ccccc1C#CC(c1ccccc1)c1ccccc1</smiles>

$41,90 \%$

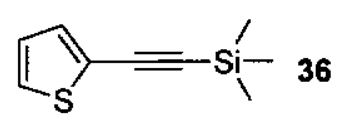

1. $\mathrm{KOH}, \mathrm{MeOH}, \mathrm{H}_{2} \mathrm{O}$

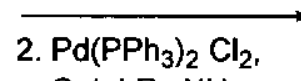
$\mathrm{Cul}, \mathrm{i}-\mathrm{Pr}_{2} \mathrm{NH}$

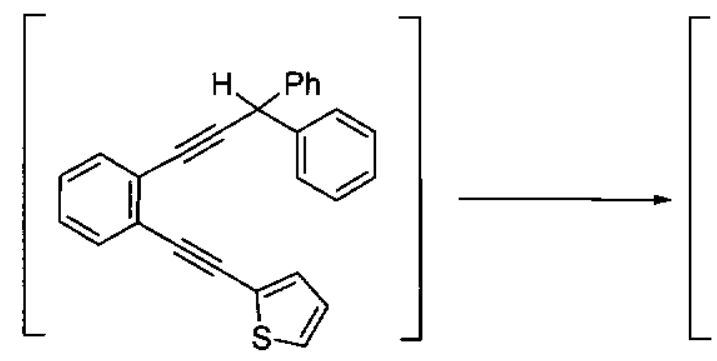

42<smiles>C(#Cc1ccccc1C=C(c1ccccc1)c1ccccc1)c1ccccc1</smiles>

43<smiles>O=S(=O)(O)O[Mg]</smiles>

Scheme 8. Synthesis of benzofluorene 30

\subsection{Development of a synthetic route for 31}

Attempted development of $\mathbf{3 1}$ using a similar procedure as described for 29 was unsuccessful (Scheme 9). However, the first two steps of the synthetic scheme were successful. The synthetic sequence outlined in Scheme 9 involved condensation of the acetylide generated from 33 with di-2-thienyl ketone (44), to give the corresponding propagylic alcohol 45 in good yields. Attempts to reduce $\mathbf{4 5}$ with triethylsilane in the presence of trifluoroacetic acid was unable to produce the expected product. Coupling 45 with phenylacetylene (46) using the Sonogashira protocol was successful. Unfortunately, treatment of 47 with thionyl chloride failed to produce $\mathbf{3 1}$ in contrast to what was observed in other related systems. 


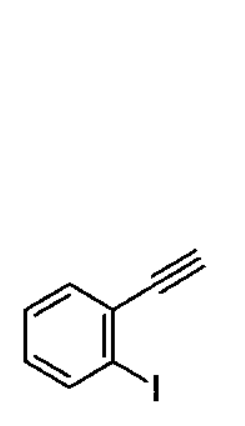

33
1. LDA, THF

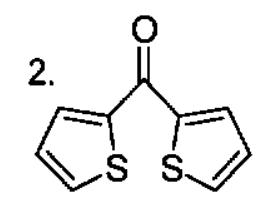

44
3. $\mathrm{H}_{2} \mathrm{O}$
年

45, $72 \%$<smiles>OC(C#Cc1ccccc1I)(c1cccs1)c1cccs1</smiles>$$
4.72 \%
$$

1. $\mathrm{SOCl}_{2}$, pyridine

2. $\mathrm{H}_{2} \mathrm{O}$
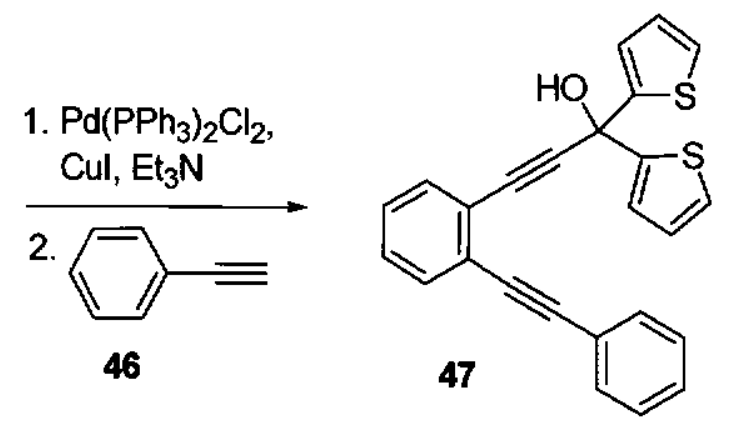

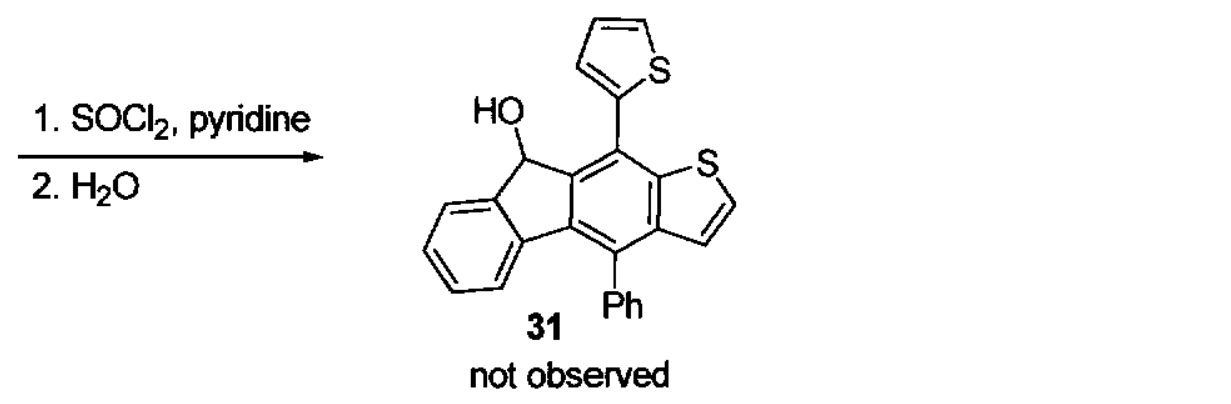

Scheme 9. Proposed synthetic route for 31

We first tested the feasibility of the Sonogashira reaction of $\mathbf{2 8}$ with phenylacetylene to give 32 and it was successful. Alternatively, the Sonogashira reaction of 28 to form $\mathbf{4 8}$ followed by a second Sonogashira reaction of $49^{28}$ and iodobenzene was also successful in producing 32 (Scheme 10). 
<smiles>Brc1cc(C2=NC(c3ccccc3)CO2)nc(C2=NC(c3ccccc3)CO2)c1</smiles>

$\frac{\text { 1. } \mathrm{Pd}(\mathrm{OAC})_{2}, \mathrm{PPh}_{3}}{\text { 2. } \mathrm{Cul}, \mathrm{Et}_{3} \mathrm{~N}, \mathrm{CH}_{2} \mathrm{Cl}_{2}}$

3. $\equiv-\mathrm{SiMe}_{3}$

$\underset{\mathrm{MeOH} / \mathrm{Et}_{2} \mathrm{O}}{10 \% \mathrm{NaOH}}$

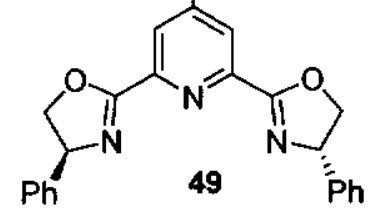<smiles>CC#Cc1cc(C2=NC(c3ccccc3)CO2)nc(C2=NC(c3ccccc3)CO2)c1</smiles><smiles>Ic1cc[c]cc1</smiles>

2. $\mathrm{Pd}(\mathrm{OAC})_{2}, \mathrm{PPh}_{3}$ refluxing $\mathrm{CH}_{2} \mathrm{Cl}_{2}, 4 \mathrm{~h}$

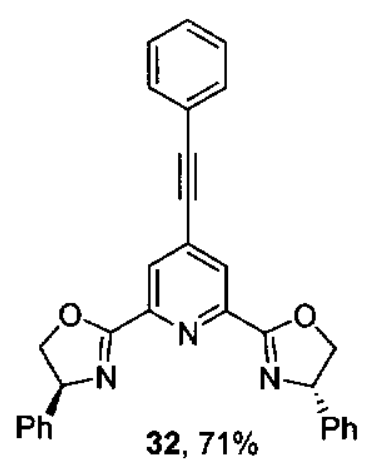

Scheme 10. Synthesis of a derivative of a pybox ligand 32

We then investigated the possibility of using pybox as substituents at the alkyne termini of $\mathbf{5 2}$ for the cascade cyclization reaction as shown in Scheme 11. However an attempt to synthesize $\mathbf{5 3}$ using 28 for the Sonogashira reaction was unsuccessful. 


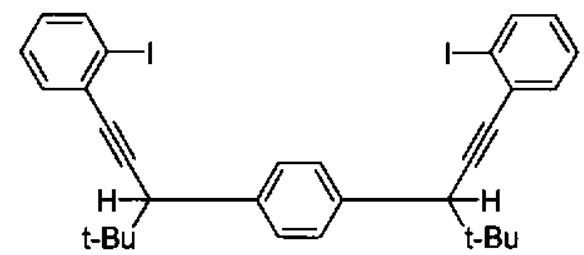

50

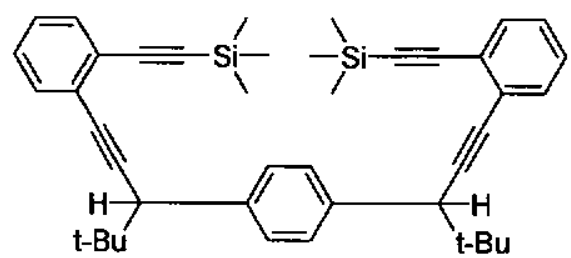

51

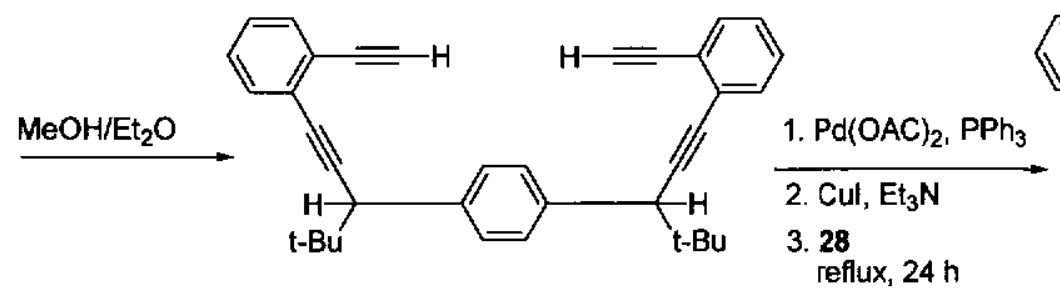

52

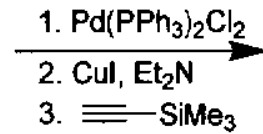

3. $\equiv-\mathrm{SiMe}_{3}$

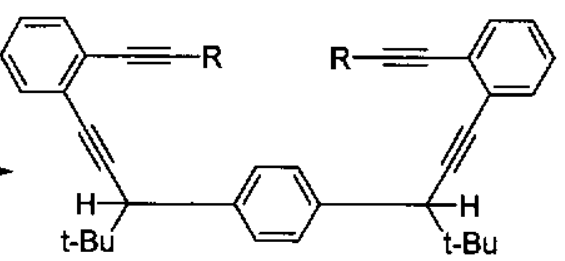

53 not formed<smiles>[R]=CC1COC(c2cc(C(C)(C)C)cc(C3=NC(c4ccccc4)CO3)n2)=N1</smiles>

Scheme 11. Preparation of pybox 28

\section{CONCLUSION}

Two benzofluorenes, 10-(1,1-dimethylethyl)-5-thienyl-11H-benzo[b]fluorene and 10phenyl-5-thienyl-11H-benzo[b]fluorene, bearing thienyl substituents were synthesized via the corresponding benzannulated enyne-allenes. The structure of 29 was established by X-ray crystallographic structure analysis. The Schmittel cyclization protocol was found to be efficient in producing benzofluorenyl systems bearing thienyl substituents. Success in the Sonogashira reaction between 2,6-bis[(4R)-4,5-dihydro-4-phenyl-2-oxazolyl]-4-ethynylpyridine and iodobenzene forms the basis of including pybox moieties in benzofluorenyl systems.

Thiophene compounds have many useful applications in various areas, including solid 
state systems. Pybox compounds have also found applications in asymmetric catalysis. Applications of benzofluorenyl compounds bearing a thiophene substituent as well as pybox bearing compounds await further investigation.

\section{EXPERIMENTAL SECTION}

Glassware used for all reactions was dried in an oven $\left(120^{\circ} \mathrm{C}\right)$ for at least 5 hours. All reactions were conducted under a dry nitrogen atmosphere. Anhydrous tetrahydrofuran (THF $\geq$ $99.9 \%$ ), diethyl ether $(\geq 99.7 \%$, , potassium tert-butoxide, tert-butanol, tert-butyllithium (1.7 M) in pentane, and lithium diisopropylamine $(1.8 \mathrm{M})$ in THF were purchased from Aldrich. Anhydrous triethylamine (99.7\%), trifluoroacetic acid (99\%), anhydrous dichloromethane (99.9 $\%$ ), and triethylsilane were purchased from Acros. Di-2-thienyl ketone and 2-iodothiophene were purchased from Alfa Aesar. $\mathrm{Pd}\left(\mathrm{PPh}_{3}\right)_{2} \mathrm{Cl}_{2}$ was purchased from Oakwood Products, Inc. Silica gel used for flash column chromatography was purchased from Dynamic Adsorbents. Melting points were uncorrected. ${ }^{1} \mathrm{H}(600 \mathrm{MHz})$ and ${ }^{13} \mathrm{C} \mathrm{NMR}(150 \mathrm{MHz})$ spectra were recorded using $\mathrm{CDCl}_{3}$ as solvent.

\section{Synthesis of propagylic alcohol 34}

To a mixture of 1-ethynyl-2-iodobenzene $(1.10 \mathrm{~g}, 4.80 \mathrm{mmol})$ in $20 \mathrm{~mL}$ of THF under a nitrogen atmosphere at $0{ }^{\circ} \mathrm{C}$ was added $3.2 \mathrm{~mL}$ of a $1.8 \mathrm{M}$ solution of lithium diisopropylamide (LDA) $(5.78 \mathrm{mmol})$. After $30 \mathrm{~min}$ of stirring, a solution of pivalophenone $(0.78 \mathrm{~g}, 4.80 \mathrm{mmol})$ in $40 \mathrm{~mL}$ of THF was introduced via cannula, and the reaction mixture was allowed to warm to room temperature. After an additional $2 \mathrm{~h}, 50 \mathrm{~mL}$ of water was introduced and the reaction mixture was extracted with diethyl ether. The combined organic extracts were washed with brine and water, dried over $\mathrm{Na}_{2} \mathrm{SO}_{4}$, and concentrated. The residue was purified by flash column 
chromatography (silica gel/10\% THF in hexanes) to produce $1.82 \mathrm{~g}$ of $\mathbf{3 4}(4.6 \mathrm{mmol}, 97 \%$ ) as a yellow oil: IR 3451, 1464, $750 \mathrm{~cm}^{-1},{ }^{1} \mathrm{H}$ NMR $\left(\mathrm{CDCl}_{3}, 600 \mathrm{MHz}\right) \delta 7.84(1 \mathrm{H}, \mathrm{dd}, J=7.8,1.2$ $\mathrm{Hz}), 7.44(3 \mathrm{H}, \mathrm{m}), 7.32(2 \mathrm{H}, \mathrm{t}, J=7.2 \mathrm{~Hz}), 7.28-7.25(2 \mathrm{H}, \mathrm{m}), 6.96(1 \mathrm{H}, \mathrm{ddd}, J=7.8,1.8 \mathrm{~Hz})$, $3.69(1 \mathrm{H}, \mathrm{s}), 1.09(9 \mathrm{H}, \mathrm{s}) ;{ }^{13} \mathrm{C} \mathrm{NMR}\left(\mathrm{CDCl}_{3}, 150 \mathrm{MHz}\right) \delta 142.0,138.9,133.3,129.6,128.0$, $127.9,127.6,100.5,96.3,87.7,79.7,40.1,25.8$; HRMS $m / z$ calcd for $\mathrm{C}_{19} \mathrm{H}_{19} \mathrm{IONa}\left(\mathrm{MNa}^{+}\right)$ 413.0373, found 413.0379 .

\section{Synthesis of compound 35}

To a mixture of $34(0.996 \mathrm{~g}, 2.55 \mathrm{mmol})$ and triethylsilane $(0.889 \mathrm{~g}, 7.66 \mathrm{mmol})$ in $50 \mathrm{~mL}$ of dichloromethane was added trifluoroacetic acid $(2.619 \mathrm{~g}, 23.0 \mathrm{mmol})$. After $1 \mathrm{~h}$ of stirring at room temperature, sodium carbonate $(1.086 \mathrm{~g}, 10.2 \mathrm{mmol})$ was added followed by $25 \mathrm{~mL}$ of water. The organic layer was separated, washed with brine and water, dried over sodium sulfate, and concentrated under reduced pressure. The residue was purified by flash column chromatography (silica gel $/ 10 \%$ diethyl ether in hexanes, $\left.\mathrm{R}_{f}=0.60\right)$ to provide $0.887 \mathrm{~g}(2.37$ mmol, $93 \%$ ) of 35 as a yellow oil: IR $1583,1264,737,704 \mathrm{~cm}^{-1} ;{ }^{1} \mathrm{H}$ NMR $\left(\mathrm{CDCl}_{3}, 600 \mathrm{MHz}\right) \delta$ $7.83(1 \mathrm{H}, \mathrm{dd} J=\mathrm{Hz}), 7.43(3 \mathrm{H}, \mathrm{ddd}, J=), 7.32(2 \mathrm{H}, \mathrm{ddd}, J=), 7.27-7.24(2 \mathrm{H}, \mathrm{m}), 6.96(1 \mathrm{H}$, td, $J={ }^{13} \mathrm{C} \mathrm{NMR}\left(\mathrm{CDCl}_{3}, 150 \mathrm{MHz}\right)$; HRMS $m / z$ calcd for $\mathrm{C}_{19} \mathrm{H}_{19} \mathrm{INa}\left(\mathrm{MNa}^{+}\right)$397.0424, found 397.0430.

\section{Synthesis of benzannulated enediyne 37}

To 2-[(2-trimethylsilylethynyl)]-thiophene $(0.36 \mathrm{~g}, 2.0 \mathrm{mmol})$ were added $\mathrm{KOH}(0.45 \mathrm{~g}, 8.0$ mmol), $\mathrm{MeOH}(2 \mathrm{~mL})$ and $\mathrm{H}_{2} \mathrm{O}(0.5 \mathrm{~mL})$. The reaction mixture was stirred for $3 \mathrm{~h}$ at room temperature. A mixture of $35(0.705 \mathrm{~g}, 1.88 \mathrm{mmol})$ in THF $(6 \mathrm{~mL}), \mathrm{Pd}\left(\mathrm{PPh}_{3}\right)_{2} \mathrm{Cl}_{2}(0.014 \mathrm{~g}, 0.02$ $\mathrm{mmol}), \mathrm{PPh}_{3}(0.010 \mathrm{~g}, 0.04 \mathrm{mmol}), \mathrm{CuI}(0.004 \mathrm{~g}, 0.019 \mathrm{mmol})$, and diisopropylamine $(1.0 \mathrm{~mL})$ 
in $6 \mathrm{~mL}$ of THF and $5.0 \mathrm{~mL}$ of toluene was then added via cannula and refluxed for 16 hours. The reaction mixture was then quenched with $\mathrm{NH}_{4} \mathrm{Cl}$ solution $(20 \mathrm{~mL})$ and extracted with methylene chloride $(3 \times 10 \mathrm{~mL})$. The organic layer was separated, washed with a $2 \mathrm{M}$ solution of $\mathrm{HCl}(20 \mathrm{~mL})$, water and brine, and then dried over $\mathrm{MgSO}_{4}$. The solvent was removed under reduced pressure, and the residue was purified by flash column chromatograph (silica gel/20\% EtOAc in hexanes, $\left.\mathrm{R}_{f}=0.33\right)$ to produce $37(1.53 \mathrm{mmol}, 81 \%)$ as a viscous, dark yellow oil: IR $1264,736,704 \mathrm{~cm}^{-1} ;{ }^{1} \mathrm{H}$ NMR $\left(\mathrm{CDCl}_{3}, 600 \mathrm{MHz}\right) \delta$ 7.53-7.51 (1 H, m), 7.46-7.43 (3 H, m) 7.29 $(1 \mathrm{H}, \mathrm{dd}, J=5.1,1.1 \mathrm{~Hz}), 7.25-7.21(6 \mathrm{H}, \mathrm{m}), 7.19(1 \mathrm{H}, \mathrm{dd}, J=3.7,1.1 \mathrm{~Hz}), 3.70(1 \mathrm{H}, \mathrm{s}), 1.06$ $(9 \mathrm{H}, \mathrm{s}) ;{ }^{13} \mathrm{C} \mathrm{NMR}\left(\mathrm{CDCl}_{3}, 150 \mathrm{MHz}\right) \delta 139.1,132.1,132.1,131.9,129.8,128.0,127.6,127.3$, $127.0,126.6,126.2,125.3,123.4,119.5,95.9,92.3,85.9,82.3,50.6,35.5,27.8$; HRMS $m / z$ calcd for $\mathrm{C}_{25} \mathrm{H}_{22} \mathrm{~S}\left(\mathrm{MNa}^{+}\right), 377.1336$ found 377.1339 .

\section{Synthesis of 10-(1,1-dimethylethyl)-5-thienyl-11 $H$-benzo[b]fluorene 29}

To $37(0.400 \mathrm{~g}, 1.13 \mathrm{mmol})$ in $20 \mathrm{~mL}$ of anhydrous toluene under an argon atmosphere was added potassium tert-butoxide $(0.281 \mathrm{~g}, 2.50 \mathrm{mmol})$ followed by 2-methyl-2-propanol $(0.038 \mathrm{~g}$, $0.51 \mathrm{mmol})$. The reaction mixture was heated under reflux for $6 \mathrm{~h}$. The reaction mixture was then allowed to cool to room temperature, and $10 \mathrm{~mL}$ of water and $50 \mathrm{~mL}$ of dichloromethane were introduced. The organic layer was separated, dried over sodium sulfate, and concentrated. The crude product was recrystallized from ethanol to yield $0.324 \mathrm{~g}$ of $29(0.91 \mathrm{mmol}, 81 \%)$ as brown crystals: $\mathrm{mp} 204-206^{\circ} \mathrm{C}$, IR 2955, 764, 730, $701 \mathrm{~cm}^{-1} ;{ }^{1} \mathrm{H} \mathrm{NMR}\left(\mathrm{CDCl}_{3}, 600 \mathrm{MHz}\right) \delta 8.61(1 \mathrm{H}$, d, $J=8.9 \mathrm{~Hz}), 7.77(1 \mathrm{H}, \mathrm{dd}, J=8.3 \mathrm{~Hz}), 7.50(1 \mathrm{H}, \mathrm{d}, J=7.5 \mathrm{~Hz}), 7.45(1 \mathrm{H}, \mathrm{ddd}, J=8.2,1.5$ $\mathrm{Hz}), 7.37(1 \mathrm{H}, \mathrm{dd}, J=8.1,0.9 \mathrm{~Hz}), 7.32(1 \mathrm{H}, \mathrm{dd}, J=5.2,5.2 \mathrm{~Hz}), 7.24(1 \mathrm{H}, \mathrm{dd}, J=7.5,0.9$ $\mathrm{Hz}), 7.09-7.08(2 \mathrm{H}, \mathrm{m}), 6.44(1 \mathrm{H}, \mathrm{d}, J=8.1 \mathrm{~Hz}) 4.51(1 \mathrm{H}, \mathrm{s}), 1.91(9 \mathrm{H}, \mathrm{s}){ }^{13} \mathrm{C} \mathrm{NMR}\left(\mathrm{CDCl}_{3}\right.$, $150 \mathrm{MHz}) \delta 144.3,142.4,140.6,140.2,139.8,137.5,135.7,131.2,127.9,127.8,127.6$, 
127.3,127.1 126.6, 126.4, 124.6, 124.5, 123.9, 123.7, 123.5, 40.2,38.9,34.3, 25.9; HRMS $m / z$ calcd for $\mathrm{C}_{25} \mathrm{H}_{23} \mathrm{~S}\left(\mathrm{MH}^{+}\right), 355.1514$ found 355.1519 .

\section{Synthesis of propagylic alcohol 40}

To a mixture of 1-ethynyl-2-iodobenzene $(0.701 \mathrm{~g}, 3.07 \mathrm{mmol})$ in $20 \mathrm{~mL}$ of THF under a nitrogen atmosphere at $0{ }^{\circ} \mathrm{C}$ was added $2.00 \mathrm{~mL}$ of a $1.8 \mathrm{M}$ solution of LDA ( $\left.3.68 \mathrm{mmol}\right)$. After $30 \mathrm{~min}$ of stirring, a solution of benzophenone $(0.56 \mathrm{~g}, 3.07 \mathrm{mmol})$ in $40 \mathrm{~mL}$ THF was introduced via cannula, and the reaction mixture was allowed to warm to room temperature. After an additional $2 \mathrm{~h}, 50 \mathrm{~mL}$ of water was introduced, and the reaction was extracted with diethyl ether. The combined organic extracts were washed with brine and water, dried over $\mathrm{Na}_{2} \mathrm{SO}_{4}$, and concentrated. The residue was purified by flash column chromatography (silica gel $/ 10 \%$ THF in hexanes, $\left.\mathrm{R}_{f}=0.33\right)$ to produce $40(1.236 \mathrm{~g} ; 98 \%)$ as a yellow oil: IR $7.02 \mathrm{~cm}^{-1}$; ${ }^{1} \mathrm{H} \mathrm{NMR}\left(\mathrm{CDCl}_{3}, 600 \mathrm{MHz}\right) \delta 7.87(1 \mathrm{H}, \mathrm{dd}, J=7.8,0.6 \mathrm{~Hz}), 7.76-7.74(4 \mathrm{H}, \mathrm{m}), 7.50(1 \mathrm{H}, \mathrm{dd}$, $J=7.7,1.6 \mathrm{~Hz}), 7.35-7.34(4 \mathrm{H}, \mathrm{m}) 7.32-7.27(3 \mathrm{H}, \mathrm{m}), 7.02(1 \mathrm{H}, \mathrm{ddd}, J=7.6,1.7 \mathrm{~Hz}), 2.94(1$ $\mathrm{H}, \mathrm{s}) ;{ }^{13} \mathrm{C}$ NMR $\left(\mathrm{CDCl}_{3}, 150 \mathrm{MHz}\right) \delta 144.6,138.3,133.0,129.8,129.0,128.3,127.8,127.7$, 126.2, 100.7, 95.2, 89.0, 75.0; HRMS $m / z$ calcd for $\mathrm{C}_{21} \mathrm{H}_{15} \mathrm{IONa}\left(\mathrm{MNa}^{+}\right) 433.0060$, found 433.0063.

\section{Synthesis of compound 41}

To a mixture of $40(1.234 \mathrm{~g}, 3.00 \mathrm{mmol})$ and triethylsilane $(1.52 \mathrm{~g}, 13.1 \mathrm{mmol})$ in $50 \mathrm{~mL}$ of dichloromethane was added trifluoroacetic acid $(3.27 \mathrm{~g}, 29.0 \mathrm{mmol})$. After $1 \mathrm{~h}$ of stirring at room temperature, sodium carbonate $(1.086 \mathrm{~g}, 10.2 \mathrm{mmol})$ was added followed by $25 \mathrm{~mL}$ of water. The organic layer was separated, washed with brine and water, dried over sodium sulfate, and concentrated under reduced pressure. The residue was purified by flash column chromatography 
(silica gel $/ 10 \%$ diethyl ether in hexanes, $\left.\mathrm{R}_{f}=0.60\right)$ to provide $1.06 \mathrm{~g}$ of $41(2.70 \mathrm{mmol}, 90 \%)$ as a yellow oil: IR $1658,1492,1463,1277,752 \mathrm{~cm}^{-1} ;{ }^{1} \mathrm{H} \mathrm{NMR}\left(\mathrm{CDCl}_{3}, 600 \mathrm{MHz}\right) \delta 7.84(1 \mathrm{H}$, dd, $J=8.4,0.6 \mathrm{~Hz}), 7.82-7.80(1 \mathrm{H}, \mathrm{m}), 7.60(1 \mathrm{H}, \mathrm{tt}, J=7.5,1.3 \mathrm{~Hz}), 7.61-7.45(4 \mathrm{H}, \mathrm{m}), 7.46(1 \mathrm{H}$, dd, $J=7.7,1.6 \mathrm{~Hz}), 7.35-7.32(3 \mathrm{H}, \mathrm{m}), 7.28(1 \mathrm{H}, \mathrm{ddd}, J=7.6,1.3 \mathrm{~Hz}), 7.24(2 \mathrm{H}, \mathrm{tt}, J=7.4$, $1.2 \mathrm{~Hz}), 6.98(1 \mathrm{H}, \mathrm{ddd}, J=7.2,1.8 \mathrm{~Hz}), 5.22(1 \mathrm{H}, \mathrm{s}) ;{ }^{13} \mathrm{C} \mathrm{NMR}\left(\mathrm{CDCl}_{3}, 150 \mathrm{MHz}\right) \delta 141.3$, $138.6,132.8,130.1,129.1,128.6,128.1,127.7,126.9,100.9,94.1,86.9,44.0 ;$ HRMS $m / z$ calcd for $\mathrm{C}_{21} \mathrm{H}_{16} \mathrm{I}\left(\mathrm{MH}^{+}\right)$395.0291, found 395.0287.

\section{Synthesis of 10-phenyl-5-thienyl-11 $H$-benzo $[b]$ fluorene 30}

To 2-[2-(trimethylsilyl)ethynyl]-thiophene $(0.32 \mathrm{~g}, 1.8 \mathrm{mmol})$ were added $\mathrm{KOH}(0.404 \mathrm{~g}, 7.2$ $\mathrm{mmol})$, water $(0.5 \mathrm{~mL})$ and methanol $(2 \mathrm{~mL})$. After $3 \mathrm{~h}$ at room temperature, a mixture of degassed 41, $\mathrm{Pd}\left(\mathrm{PPh}_{3}\right)_{2} \mathrm{Cl}_{2}(0.014 \mathrm{~g}, 0.020 \mathrm{mmol}), \mathrm{PPh}_{3}(0.010 \mathrm{~g}, 0.040 \mathrm{mmol}), \mathrm{CuI}(0.036 \mathrm{~g}$, $0.019 \mathrm{mmol})$, diisopropylamine $(1.0 \mathrm{~mL})$ and toluene $(5.0 \mathrm{~mL})$ was added via cannula. After 16 $\mathrm{h}$ at room temperature, saturated ammonium chloride solution $(20 \mathrm{~mL})$ was then added. The organic layer was separated and extracted with methylene chloride $(3 \times 10 \mathrm{~mL})$, washed with a 2 $\mathrm{M}$ solution of $\mathrm{HCl}(20 \mathrm{~mL})$, water and brine and, dried over $\mathrm{Na}_{2} \mathrm{SO}_{4}$ and concentrated. The crude product was recrystallized from ethanol to yield $0.511 \mathrm{~g}$ of $30(1.36 \mathrm{mmol}, 91 \%)$ as brown crystals: IR $1369,1029,762,725,701 \mathrm{~cm}^{-1} ;{ }^{1} \mathrm{H}$ NMR $\left(\mathrm{CDCl}_{3}, 600 \mathrm{MHz}\right) \delta 7.82(1 \mathrm{H}, \mathrm{dd}, J=$ 8.3, 0.7 Hz), 7.67-7.65 (2 H, m), 7.60-7.57 $(2 \mathrm{H}, \mathrm{m}), 7.52(1 \mathrm{H}, \mathrm{tt}, J=7.4,1.3 \mathrm{~Hz}), 7.47(2 \mathrm{H}, \mathrm{d}$, 3.3), 7.45-7.43 (2 H, m), 7.4-7.38 $(1 \mathrm{H}, \mathrm{m}), 7.36(1 \mathrm{H}, \mathrm{dd}, J=5.3,3.4 \mathrm{~Hz}), 7.25(2 \mathrm{H}$, ddd, $J=$ $7.3,1.0 \mathrm{~Hz}) 7.19(1 \mathrm{H}, \mathrm{dd}, J=3.4,2.0 \mathrm{~Hz}), 7.14(1 \mathrm{H}, \mathrm{ddd}, J=7.9,0.8 \mathrm{~Hz}), 6.68(1 \mathrm{H}, \mathrm{d}, J=7.9$ $\mathrm{Hz}), 3.87(2 \mathrm{H}, \mathrm{s}) ;{ }^{13} \mathrm{C} \mathrm{NMR}\left(\mathrm{CDCl}_{3}, 150 \mathrm{MHz}\right) \delta 144.4,141.0,139.4,139.3,139.0,136.4$, 
$134.3,131.4,129.8,128.7,127.9,127.4,126.7,126.7,126.1,125.7,125.5,125.4,124.8,124.7$,

123.8, 36.6; HRMS $m / z$ calcd for $\mathrm{C}_{27} \mathrm{H}_{18} \mathrm{~S}\left(\mathrm{MNa}^{+}\right)$397.1021, found 397.1023 .

\section{Synthesis of propagylic alcohol 45}

To a mixture of 1-ethynyl-2-iodobenzene $(0.775 \mathrm{~g}, 3.34 \mathrm{mmol})$ in $20 \mathrm{~mL}$ of THF under a nitrogen atmosphere at $0{ }^{\circ} \mathrm{C}$ was added $2.26 \mathrm{~mL}$ of a $1.8 \mathrm{M}$ solution of LDA (4.08 mmol). After 30 min of stirring, a solution of di-2-thithienyl ketone $(0.66 \mathrm{~g}, 3.40 \mathrm{mmol})$ in $40 \mathrm{~mL}$ of THF was introduced via cannula, and the reaction mixture was allowed to warm to room temperature. After an additional $2 \mathrm{~h}, 50 \mathrm{~mL}$ of water was introduced, and the reaction mixture was extracted with dichloromethane. The combined organic extracts were washed with brine and water, dried over $\mathrm{Na}_{2} \mathrm{SO}_{4}$, and concentrated. The residue was purified by flash column chromatography (silica gel $/ 20 \%$ THF in hexanes) to produce $0.688 \mathrm{~g} 45$ (1.63 mmol; $72 \%$ ) as a dark oil: IR 1462, 1230, 1015, $837735,753,697 \mathrm{~cm}^{-1} ;{ }^{1} \mathrm{H}$ NMR $\left(\mathrm{CDCl}_{3}, 600 \mathrm{MHz}\right) 7.86(1 \mathrm{H}, \mathrm{d}, J=7.9 \mathrm{~Hz}), 7.52$ $(1 \mathrm{H}, \mathrm{dd}, J=7.6,1.5 \mathrm{~Hz}), 7.35-7.30(5 \mathrm{H}, \mathrm{m}), 7.04(1 \mathrm{H}, \mathrm{ddd}, J=7.9,1.6 \mathrm{~Hz}), 6.98(2 \mathrm{H}, \mathrm{dd}, J=$ 5.0, $3.7 \mathrm{~Hz}), 3.31(1 \mathrm{H}, \mathrm{s}) ;{ }^{13} \mathrm{C} \mathrm{NMR}\left(\mathrm{CDCl}_{3}, 150 \mathrm{MHz}\right) \delta 148.8,138.8,133.1,130.1,128.5$, $127.8,126.5,126.1,125.8,100.6,93.6,88.0,70.1 ; \mathrm{HRMS} m / z$ calcd for $\mathrm{C}_{17} \mathrm{H}_{11} \mathrm{IOS}_{2} \mathrm{Na}\left(\mathrm{MNa}^{+}\right)$ 444.9188, found 444.9191 .

\section{Synthesis of benzannulated enediynyl alcohol 47}

To a mixture of $45(0.300 \mathrm{~g}, 0.71 \mathrm{mmol}), \mathrm{Pd}\left(\mathrm{PPh}_{3}\right)_{2} \mathrm{Cl}_{2}(0.03 \mathrm{~g}, \mathrm{mmol})$, and $\mathrm{Cul}(0.003 \mathrm{~g}, \mathrm{mmol})$ in $20 \mathrm{~mL}$ of triethylamine under a nitrogen atmosphere was added via cannula a solution of phenylacetylene $(0.075 \mathrm{~g}, 0.71 \mathrm{mmol})$ in $10 \mathrm{~mL}$ of triethylamine. The resulting mixture was allowed to react for $12 \mathrm{~h}$ at room temperature and washed with water, then brine and extracted with dichloromethane $(3 \times 10 \mathrm{~mL})$. The organic layer was separated, dried over sodium sulfate, 
and concentrated. The residue was purified by flash column chromatography (silica gel $/ 20 \%$ EtOAc in hexanes, $\mathrm{R}_{f}=0.53$ ), to provide 47 as a dark solution: $\mathrm{IR} 3526,1494,1231,1024,756$, 702, $691 \mathrm{~cm}^{-1} ;{ }^{1} \mathrm{H}$ NMR $\left(\mathrm{CDCl}_{3}, 600 \mathrm{MHz}\right) \delta$ 7.57-7.54 (2 H, m), 7.43-7.41 (2 H, m), 7.36-7.28

$(2 \mathrm{H}, \mathrm{m}), 7.25(2 \mathrm{H}, \mathrm{dd}, J=5.1,1.3 \mathrm{~Hz}), 7.84(2 \mathrm{H}, \mathrm{dd}, J=5.1,3.7 \mathrm{~Hz}), 3.28(1 \mathrm{H}, \mathrm{s}) ;{ }^{13} \mathrm{C} \mathrm{NMR}$ $\left(\mathrm{CDCl}_{3}, 150 \mathrm{MHz}\right) \delta 149.1,132.3,132.0,131.8,128.7,128.5,128,3,128.0,126.5,126.1,126.0$, 125.8, 124.3,123.0, 94.0, 88.0, 85.0, 70.1; HRMS $m / z$ calcd for $\mathrm{C}_{25} \mathrm{H}_{16} \mathrm{OS}_{2} \mathrm{Na}\left(\mathrm{MNa}^{+}\right) 419.0535$, found 419.0535 .

Synthesis of 2,6-bis[(4R)-4,5-dihydro-4-phenyl-2-oxazolyl]-4-ethynylpyridine, 32. To a mixture of iodobenzene $(0.150 \mathrm{~g}, 0.735 \mathrm{mmol}), \mathrm{Pd}(\mathrm{OAc})_{2}(0.013 \mathrm{~g}, \mathrm{mmol}), \mathrm{PPh}_{3}(0.030 \mathrm{~g}, 0.114$ $\mathrm{mmol})$, and $\mathrm{Cul}(0.003 \mathrm{~g}, 0.016 \mathrm{mmol})$ in $3 \mathrm{~mL}$ of triethylamine under a nitrogen atmosphere were added via cannula a solution of $49(0.300 \mathrm{~g}, 0.668 \mathrm{mmol})$ in $10 \mathrm{~mL}$ of dichloromethane. The resulting mixture was refluxed for $4 \mathrm{~h}$ and washed with water and brine and, extracted with dichloromethane $(3 \times 10 \mathrm{~mL})$. The combined organic layers were dried over sodium sulfate and concentrated. The residue was recrystallized from hexanes to yield $0.259 \mathrm{~g}$ of $32(0.553 \mathrm{mmol}$, $83 \%)$ as brown crystals: IR $1265,736,705 \mathrm{~cm}^{-1}$; ${ }^{1} \mathrm{H} \mathrm{NMR}\left(\mathrm{CDCl}_{3}, 600 \mathrm{MHz}\right) \delta 8.44(2 \mathrm{H}, \mathrm{s})$, $7.52(2 \mathrm{H}, \mathrm{d}, \mathrm{J}=6.6 \mathrm{~Hz}), 7.40-7.30(13 \mathrm{H}, \mathrm{m}), 5.48(2 \mathrm{H}, \mathrm{t}, J=9.1 \mathrm{~Hz}), 4.95(2 \mathrm{H}, \mathrm{dd}, J=8.8$ $\mathrm{Hz}), 4.45(2 \mathrm{H}, \mathrm{t}, J=8.6 \mathrm{~Hz}) ;{ }^{13} \mathrm{C} \mathrm{NMR}\left(\mathrm{CDCl}_{3}, 150 \mathrm{MHz}\right) \delta 163.2,163.0,147.0,141.6,133.4$, $132.0,129.6,128.8,128.6,128.0,127.8,126.8,121.6,96.0,85.6,75.6,70.3 ;$ HRMS $m / z$ calcd for $\mathrm{C}_{31} \mathrm{H}_{24} \mathrm{~N}_{3} \mathrm{O}_{2}\left(\mathrm{MH}^{+}\right) 470.1868$, found 470.1860 . 


\section{REFERENCES}

1. Ho, C.-L.; Wong, W.-Y. Coordination Chemistry Reviews 2011, 255, 2469-2502.

2. Halik, M.; Klauk, H.; Zschieschang, U.; Schmid, G.; Ponomarenko, S.; Kirchmeyer, S.; Weber, W. Adv. Mater., 2003, 15, 917.

3. Breslow, R.; Foss, F. W. Jr. J. Phys Condens. Matter 2008, 20, 374104

4. Lecle're, Ph.; Surin, M.; Brocorens, P.; Cavallini,M.; Biscarini, F.; Lazzaroni, R. Materials Science and Engineering R 2006, 55, 1-56

5. Shaytan, A. K.; Schillinger, E. -K.; Mena-Osteritz, E.; Schmid, S.; Khalatur, P. G.; Bäuerle, P.; Khokhlov, A. R.; Beilstein J. Nanotechnol. 2011, 2, 525-544

6. Hoofman, R. J. O. M; de Haas, M.; Siebbeles, D. A.; Warmann, J. M. Nature 1998, 392, 54

7. Perepichka, I. F.; Perepichka, D. F.; Zade, S. S.; Bendikov; M. 2009

8. Brunetti, F. G.; Kumarb, R.; Wudl, F. J. Mater. Chem., 2010, 20, 2934-2948

9. Zmija, J.; Malachowski, M. J. Journal of Acheivements in Materials and Manufacturing Engineering 2011, 48, 14-21

10. Loveday, D. C.; Hmyene, M.; Ferraris, J. P.; Synthetic Metals 1997, 84 245-246

11. Shiota, N.; Kinuta, T.; Sato, T.; Tajima, N.; Kuroda, R.; Matsubara, Y.; Imai; Y. Crystal Growth \& Design, 2010, 10, 1341-1345

12. (a) Myers, A. G.; Kuo, E. Y.; Finney, N. S. J. Am. Chem. Soc.1989, 111, 8057-8059. (b) Nagata, R.; Yamanaka, H.; Okazaki, E.; Saito, I. Tetrahedron Lett. 1989, 30, 4995-4998. 
13. Schmittel, M.; Vavilala, C. J. Org. Chem. 2005, 70, 4865-4868.

14. a) Schmittel, M.; Strittmatter, M.; Kiau, S. Tetrahedron Lett. 1995, 36, 4975-4978. (b) Schmittel, M.; Strittmatter, M.; Vollmann, K.; Kiau, S. Tetrahedron Lett. 1996, 37, 99-1002.

15. Li, H.; Yang, H.; Petersen, J. L.; Wang, K. K.; J. Org. Chem. 2004, 69, 4500-4508.

16. (a) Engels, B.; Lennartz, C.; Hanrath, M.; Schmittel, M.;Strittmatter, M. Angew. Chem., Int. Ed. Engl. 1998, 37, 1960-1963. (b) Schmittel, M.; Kiau, S.; Siebert, T.; Strittmatter, M. Tetrahedron Lett. 1996, 37, 7691-7694.

17. Li, H.; Zhang, H.-R.; Petersen, J. L.; Wang, K. K. J. Org. Chem. 2001, 66, 6662-6668

18. Schmittel, M.; Strittmatter, M.; Vollmann, K.; Kiau, S. Tetrahedron Lett. 1996, 37, 999-1002.

19. Schmittel, M.; Strittmatter, M.; Kiau, S. Angew. Chem., Int. Ed. 1996, 35, 1843-1845.

20. Schmittel, M.; Keller, M.; Kiau, S.; Strittmatter, M. Chem. Eur. J. 1997, 3, 807-816.

21. Schmittel, M.; Maywald, M. Chem. Commun. 2001, 155-156.

22. Wang, K. K. Modern Allene Chemistry; Krause, N., Hashmi, A. S. K., Eds.; Wiley-VCH: Weinheim, Germany, 2004; Vol. 2, pp 1091-1126.

23. Dai, W.; Petersen, J. L. and Wang, K. K J. Org. Chem. 2005, 70, 6647-6652

24. Wen, B.; Petersen, J. L. and Wang; K. K Chem. Commun. 2010, 46, 1938-1940

25. Nishiyama, H. Adv. Catal. Proc. 1997, 2, 153-188. (b) Desimoni, G.; Faita, G.; Quadrelli, P. Chem. Rev. 2003, 103, 3119-3154. 
26. (a) Ojima, I. Catalytic Asymmetric Synthesis; John Wiley \& Sons:New York, 2000. (b) Noyori, R. Asymmetric Catalysis in Organic Synthesis; John Wiley \& Sons: New York, 1994. (c) Seyden-Penne, J. Chiral Auxiliaries and Ligands in Asymmetric Synthesis; John Wiley \& Sons: New York, 1995

27. Pryor, K. E.; Shipps, G. W., Jr.; Skyler, D. A.; Rebek, J., Jr. Tetrahedron 1998, 54, 4107-4124.

28. Tilliet, M.; Lundgren, S.; Moberg, C.; Levacher, V. Advanced Synthesis \& Catalysis 2007, 349, 2079-2084. 
\%

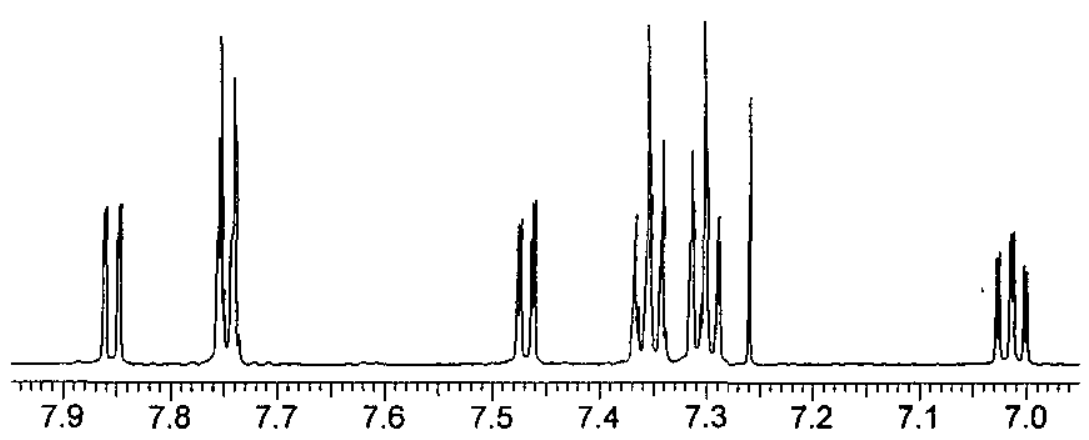

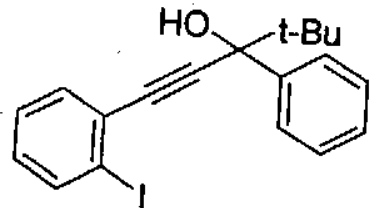

34

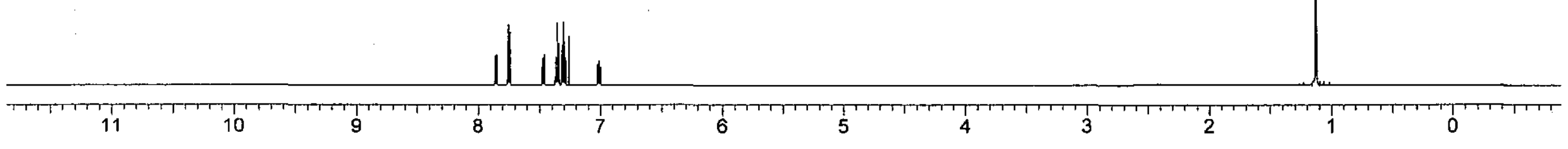




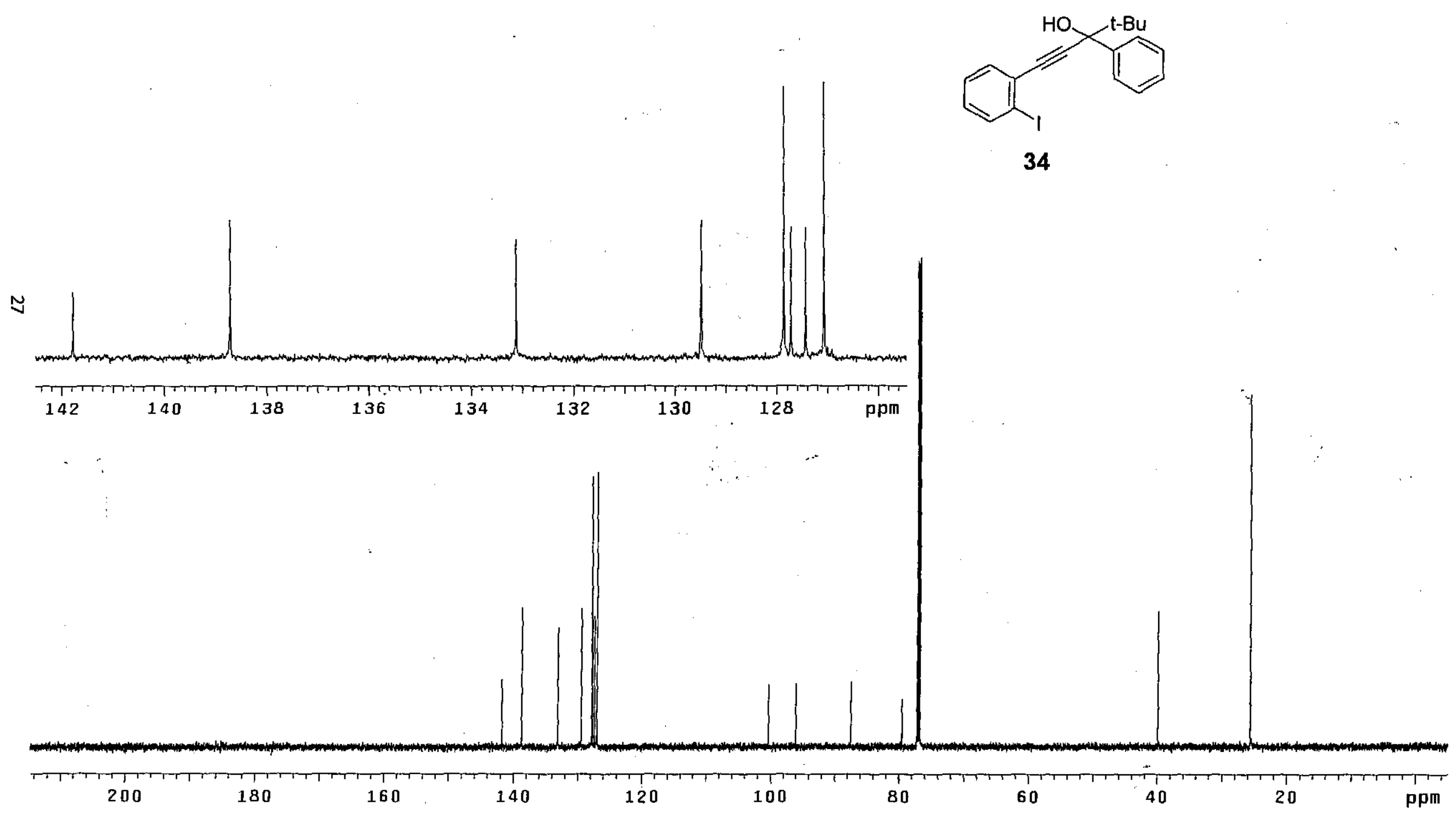




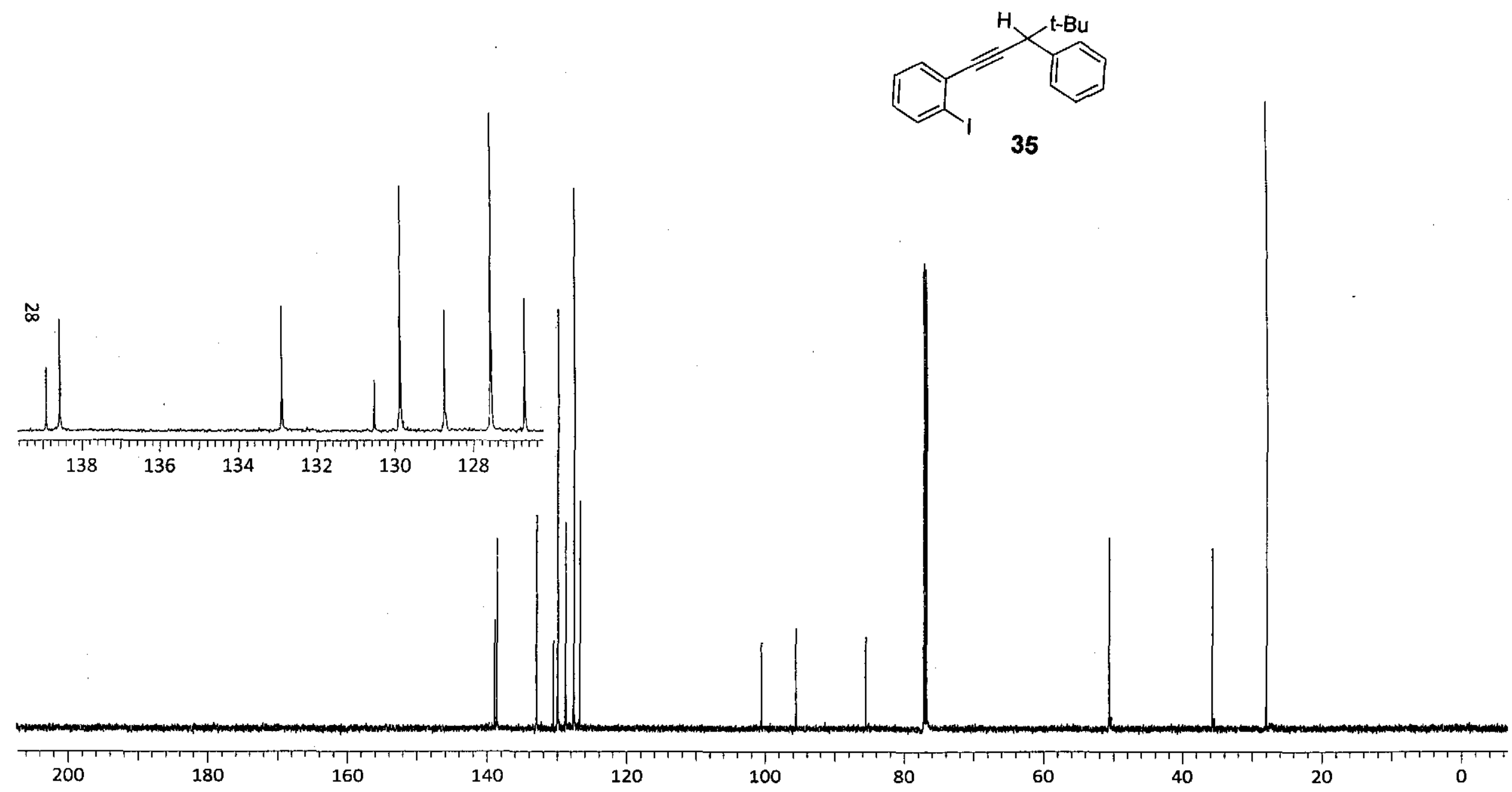


$\widetilde{1}$

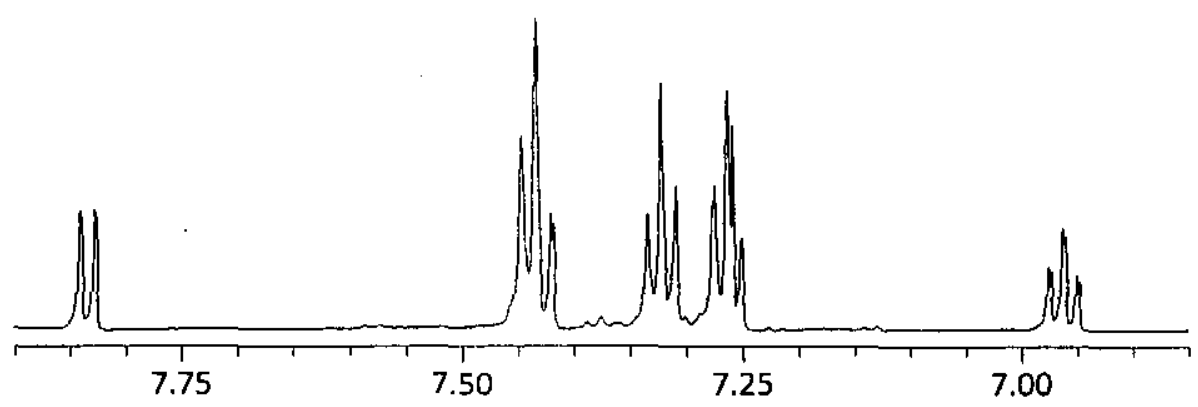

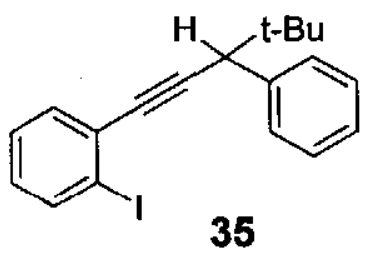

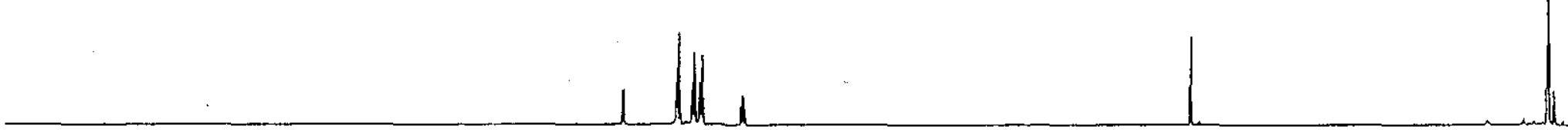



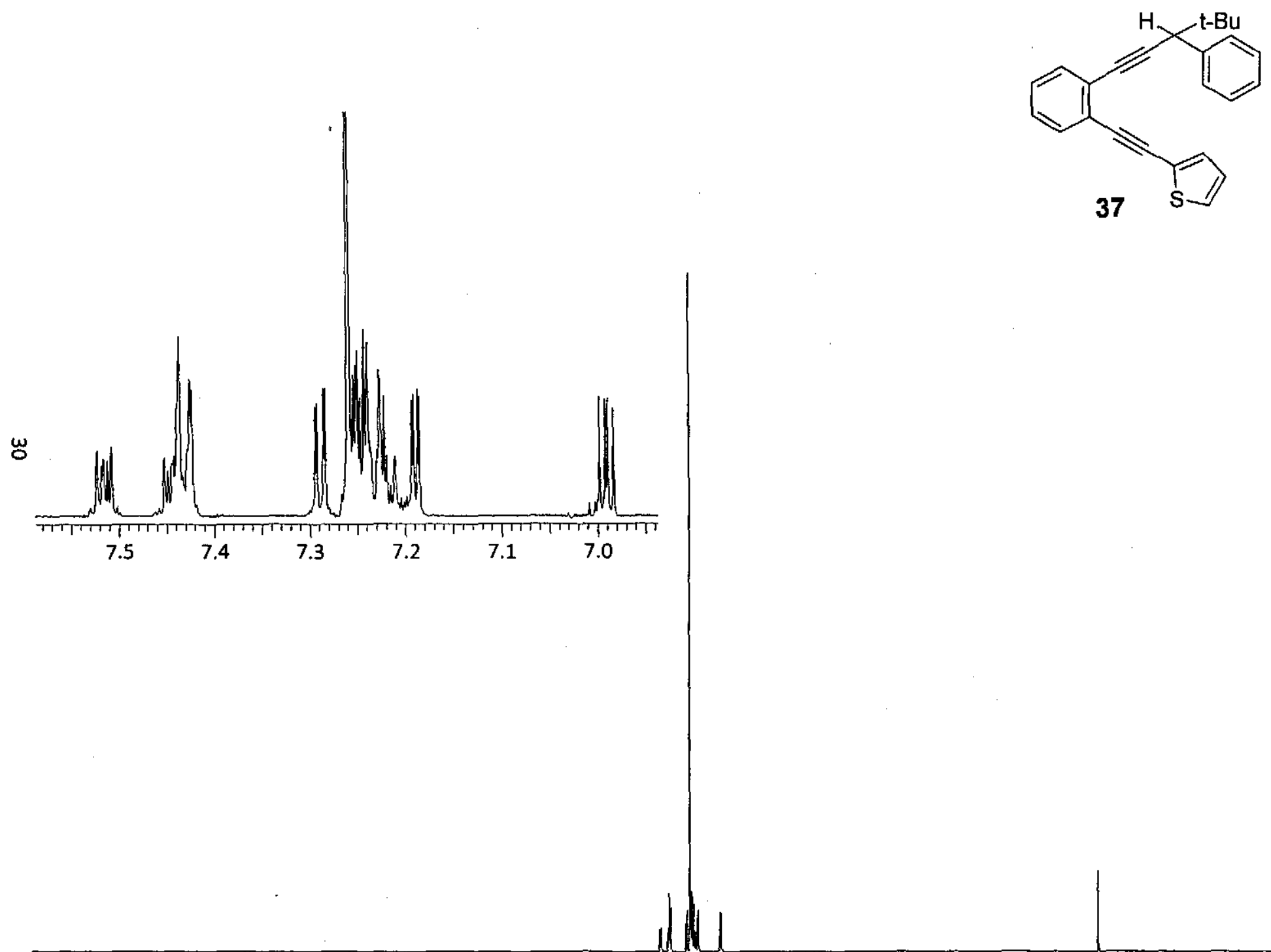

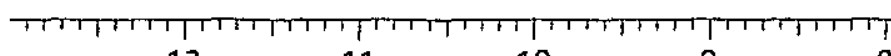




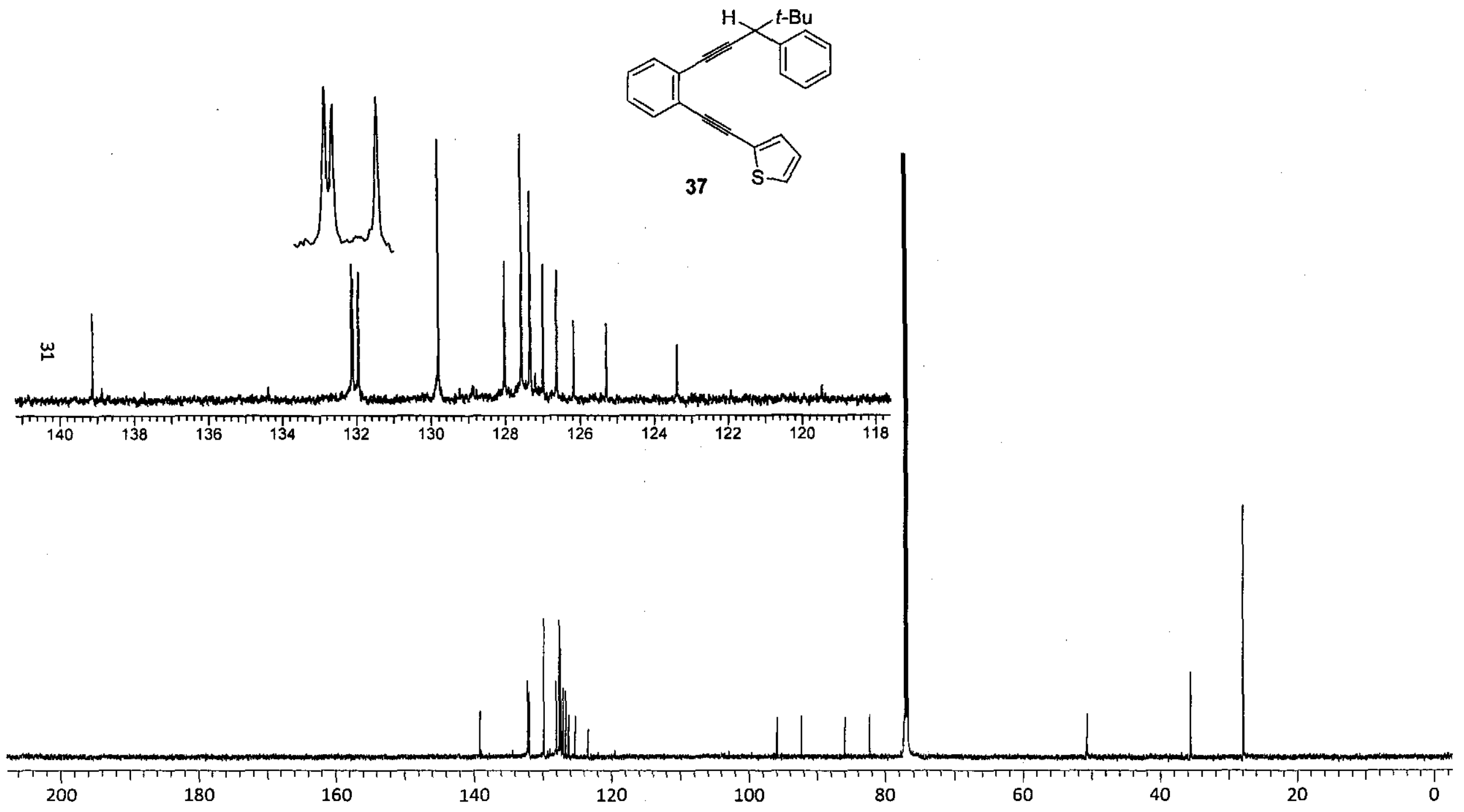




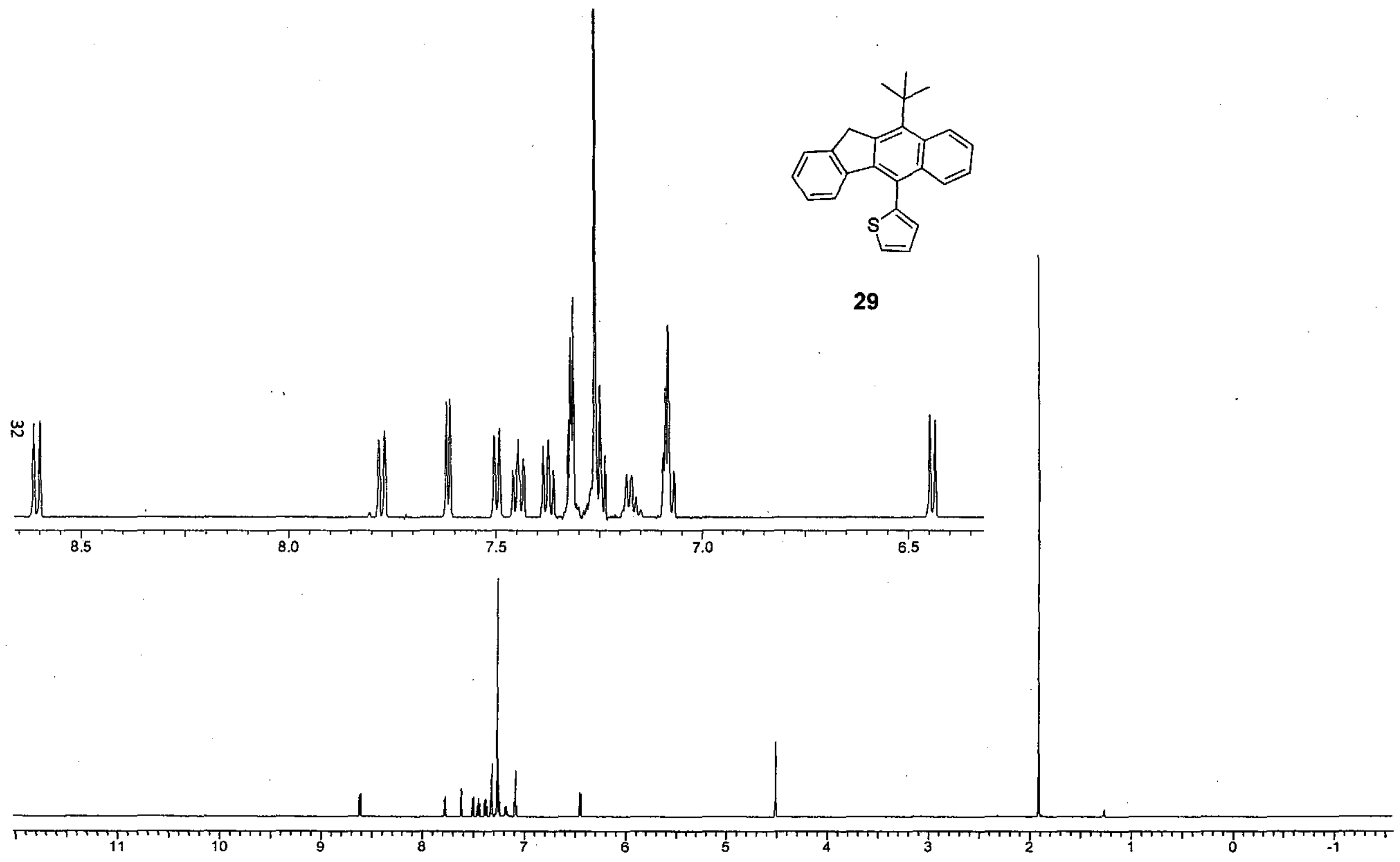




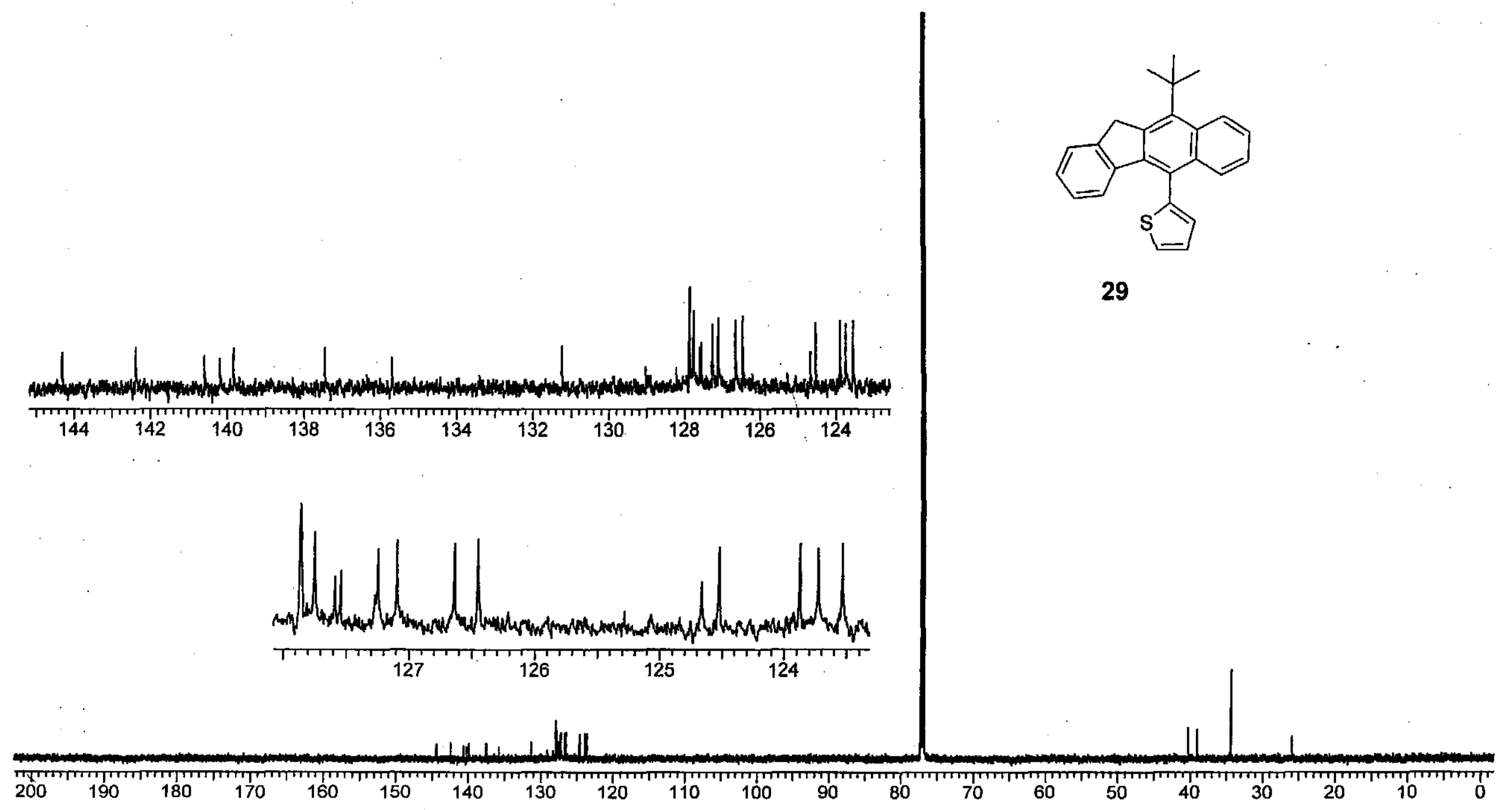




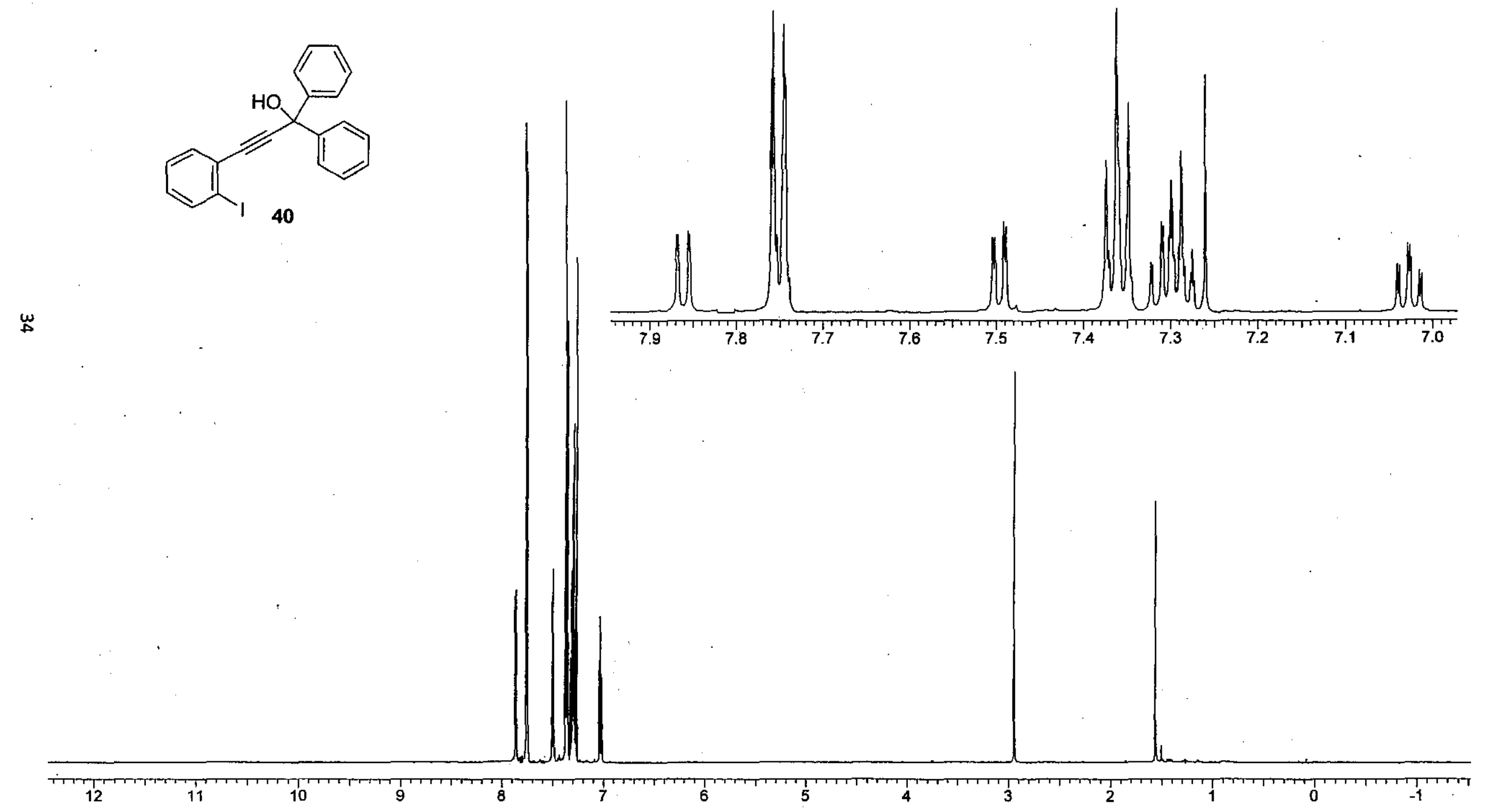



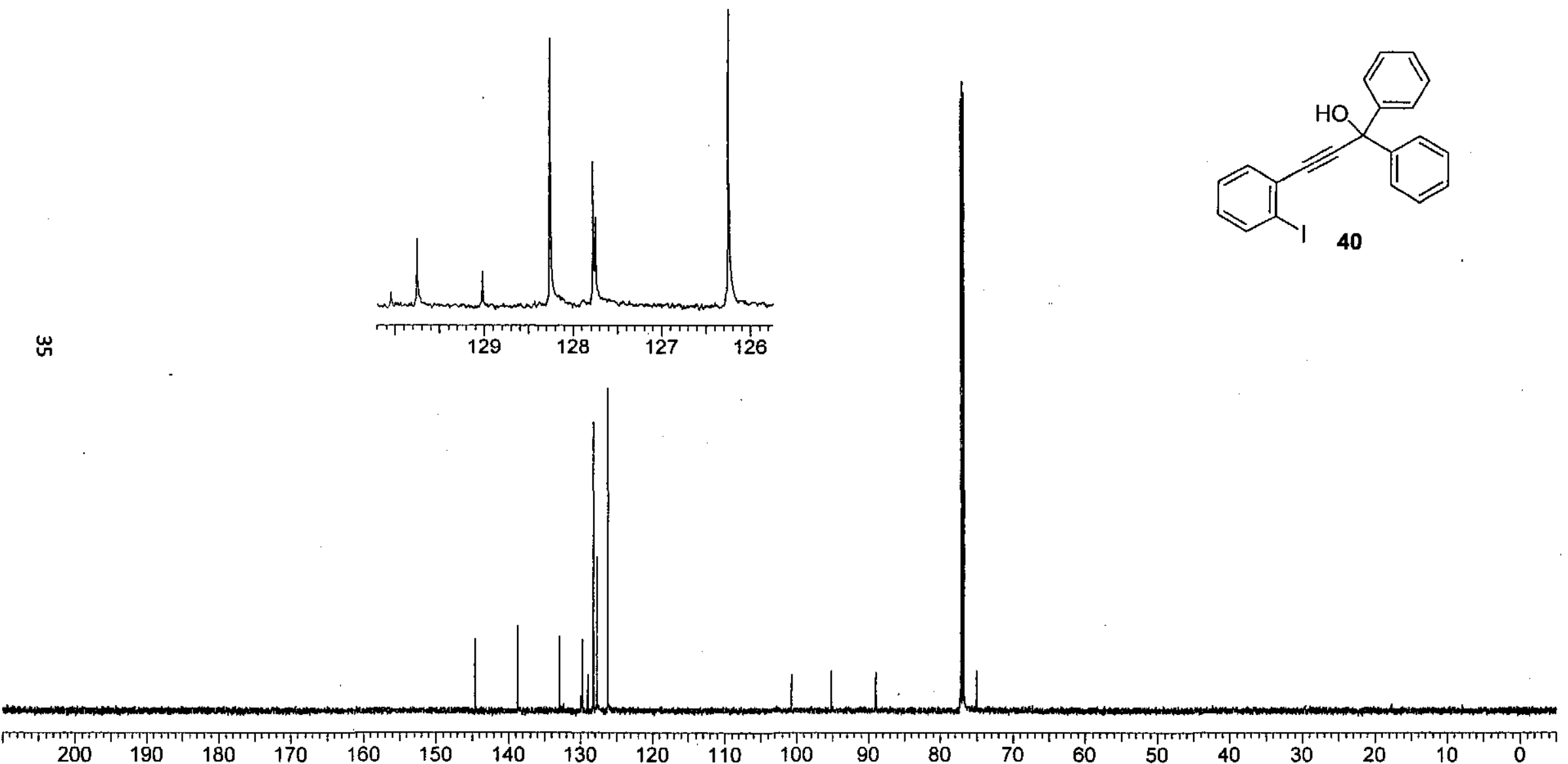


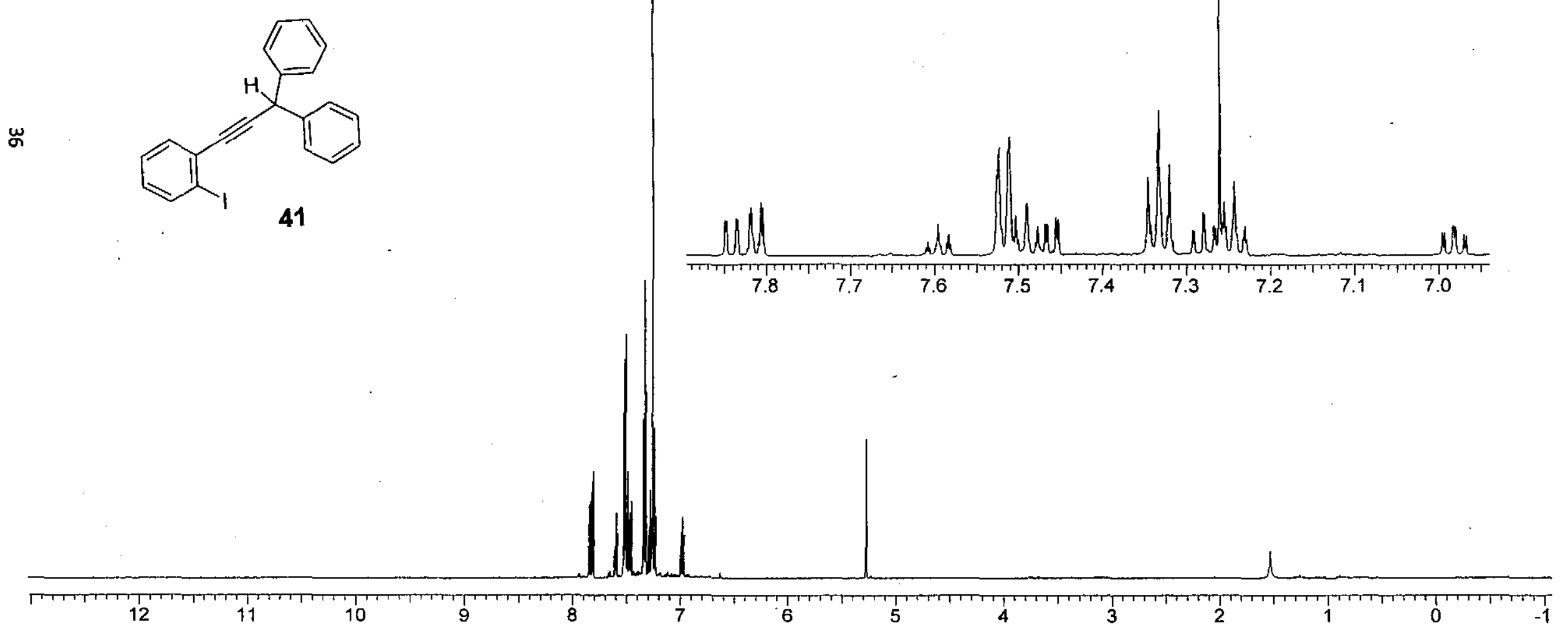




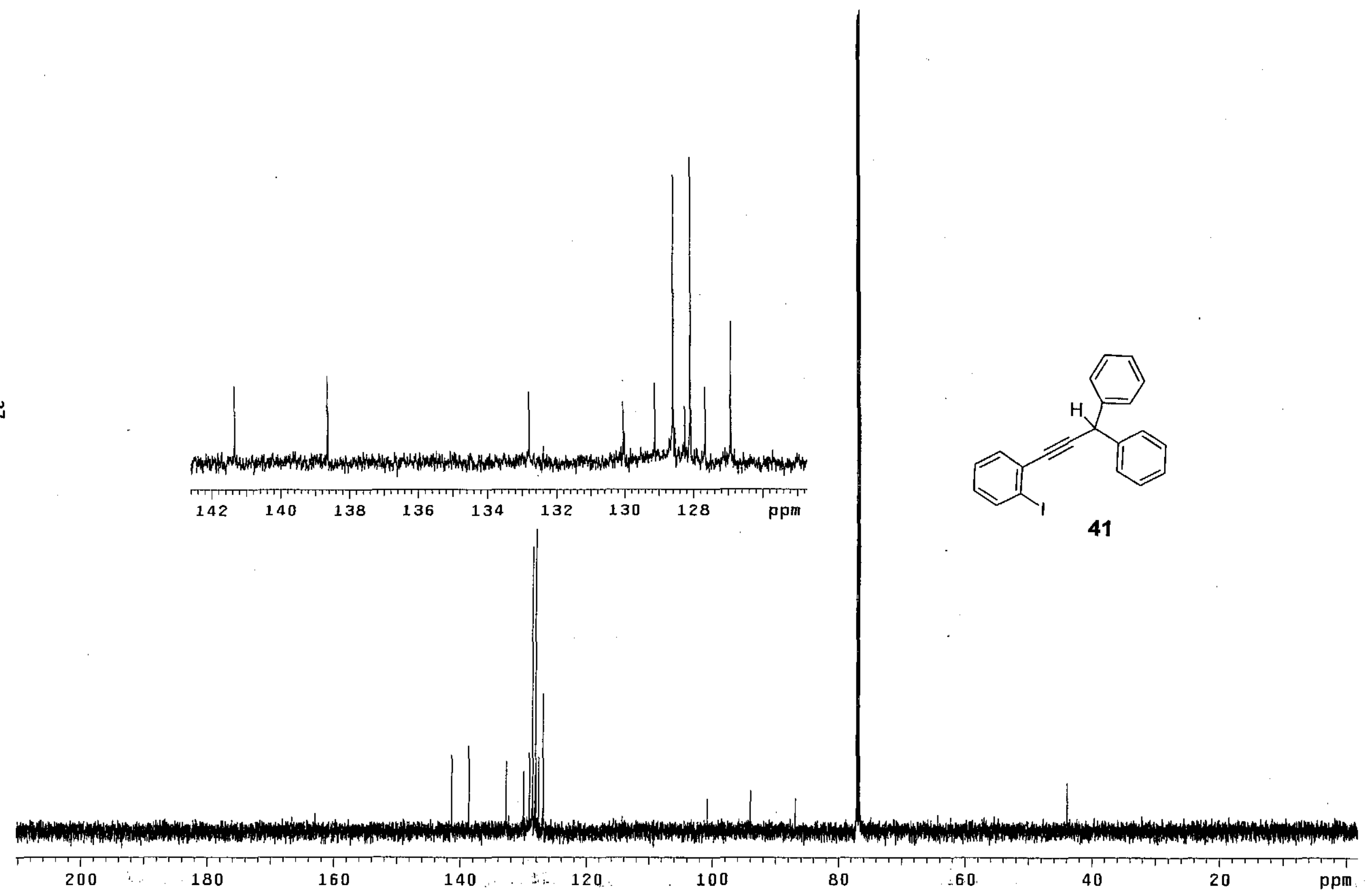




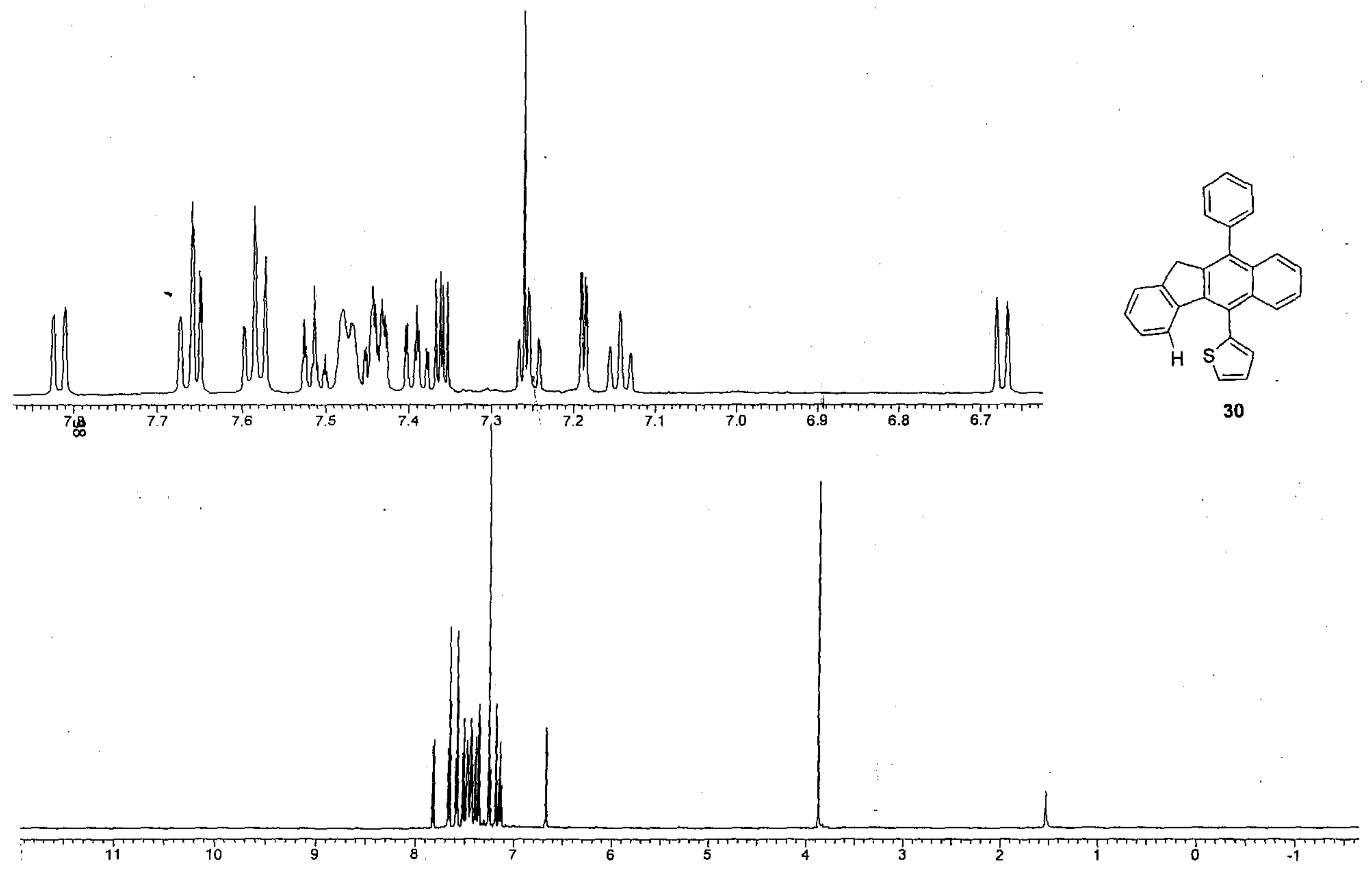




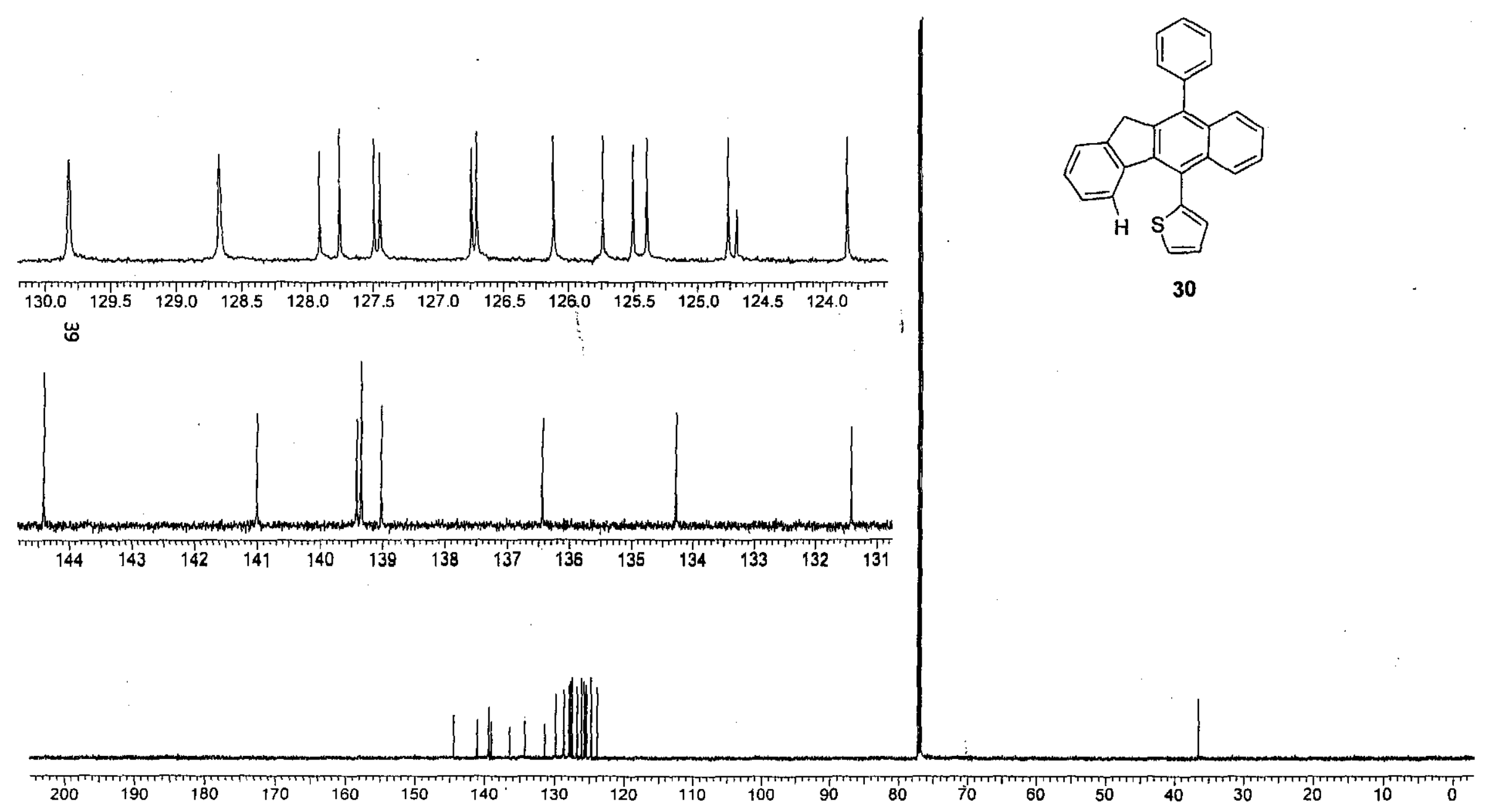




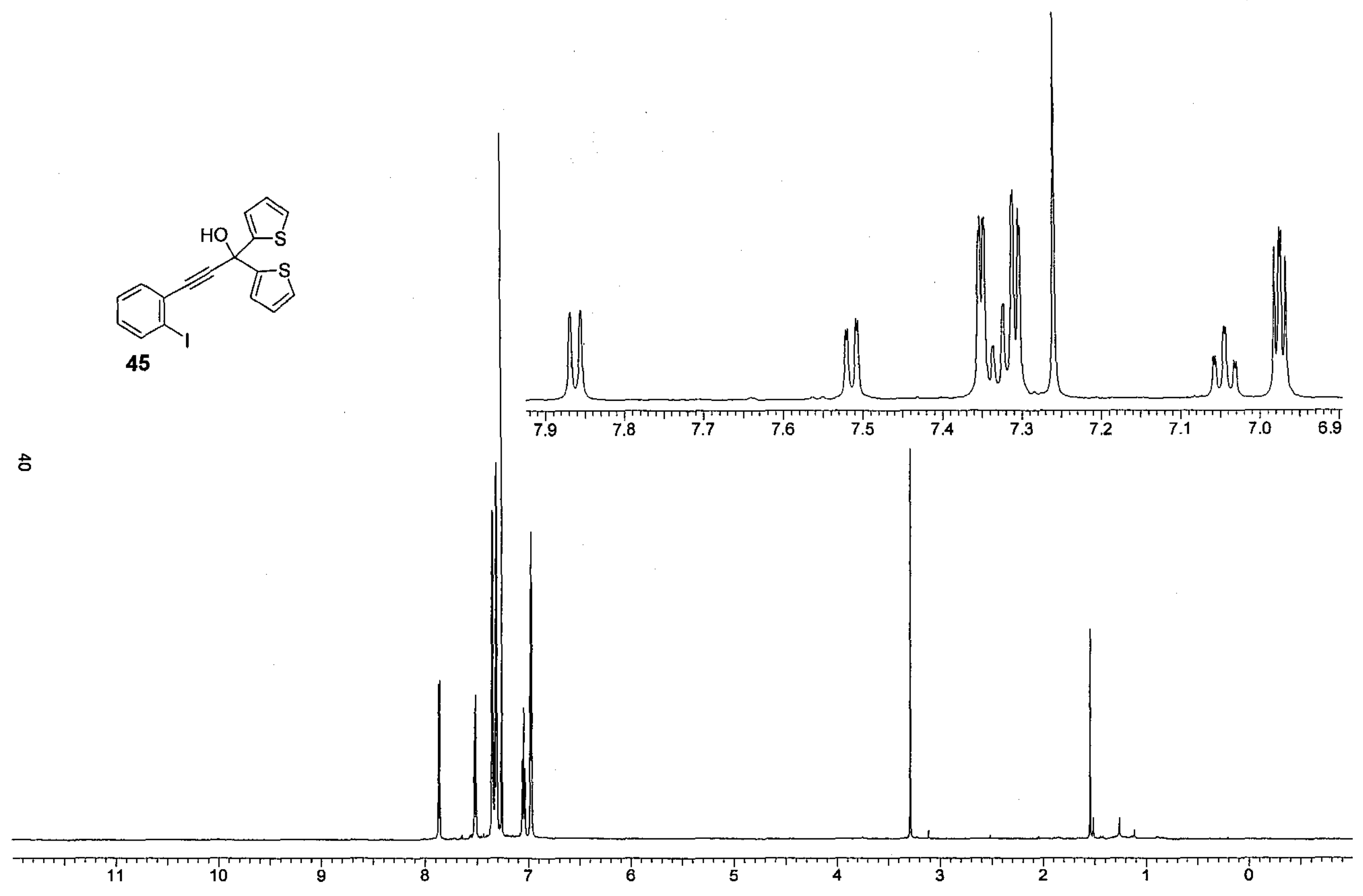


$t$

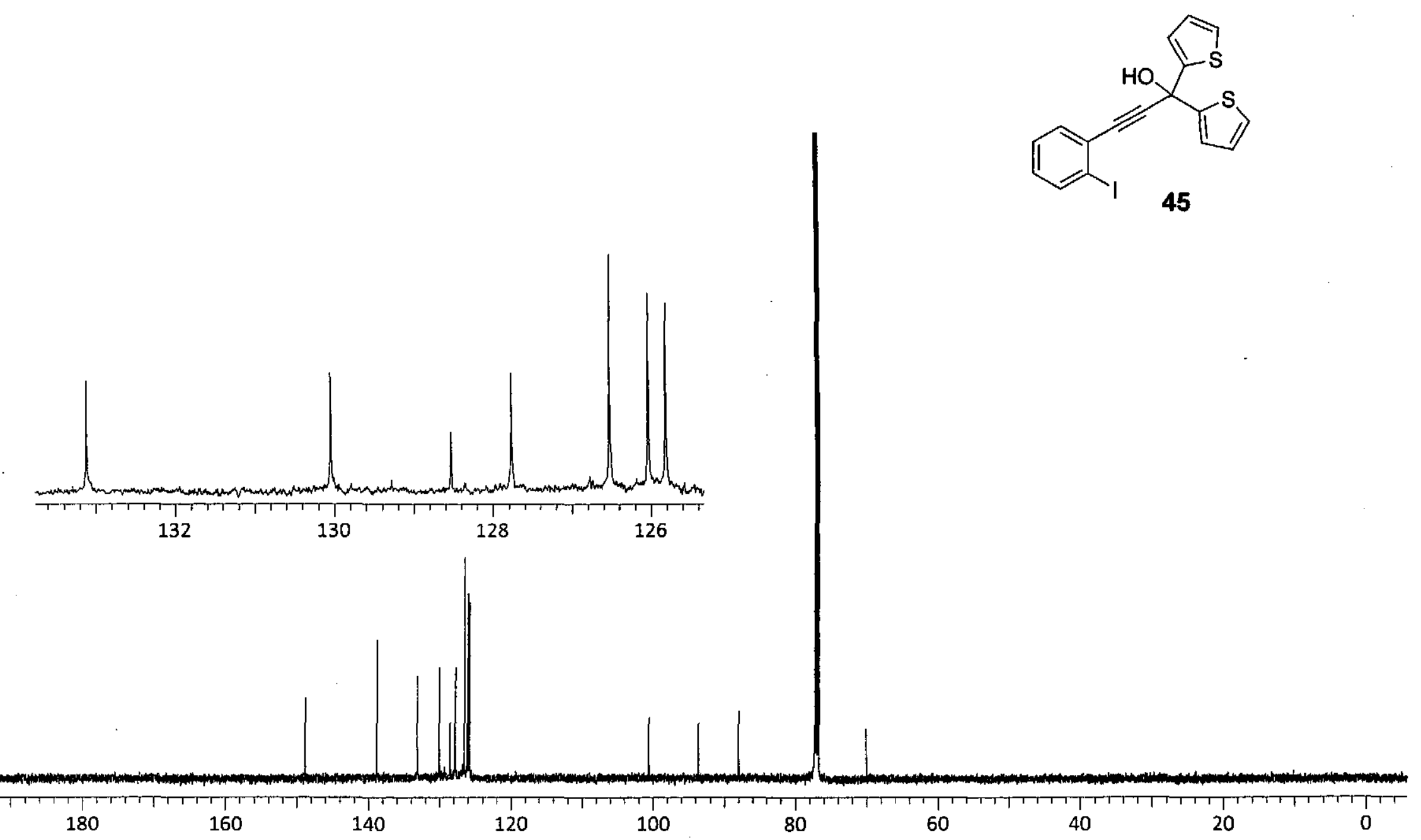




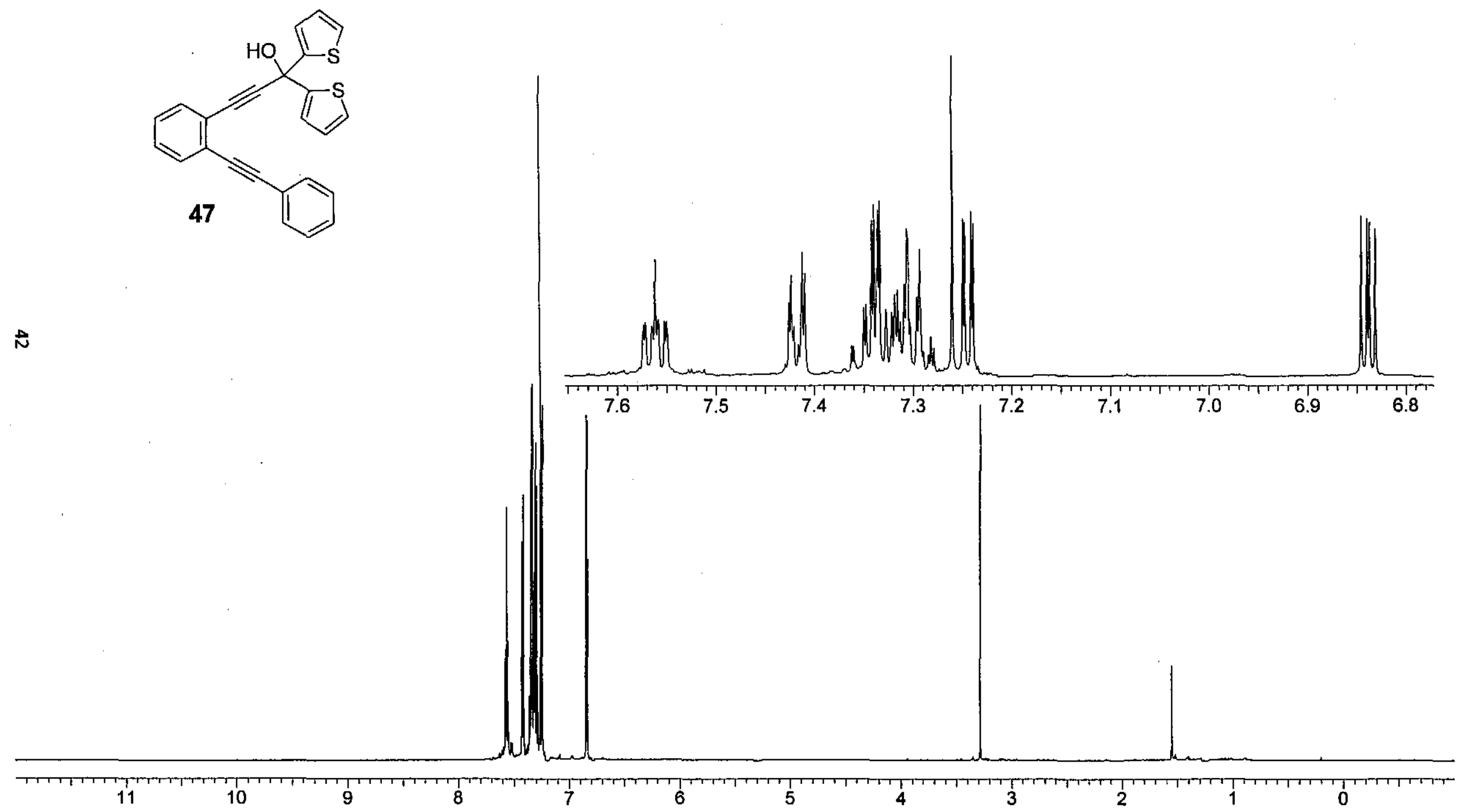



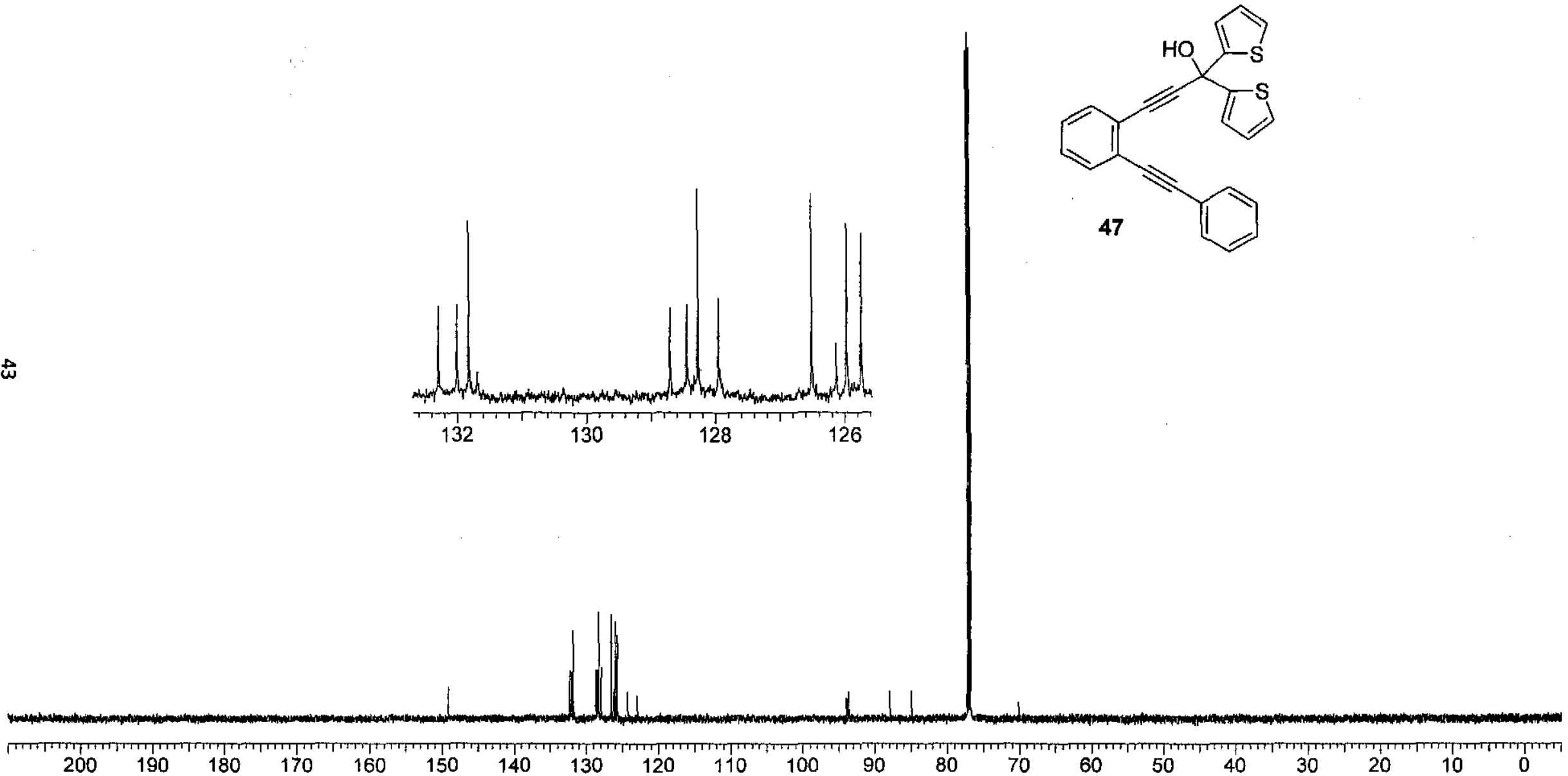


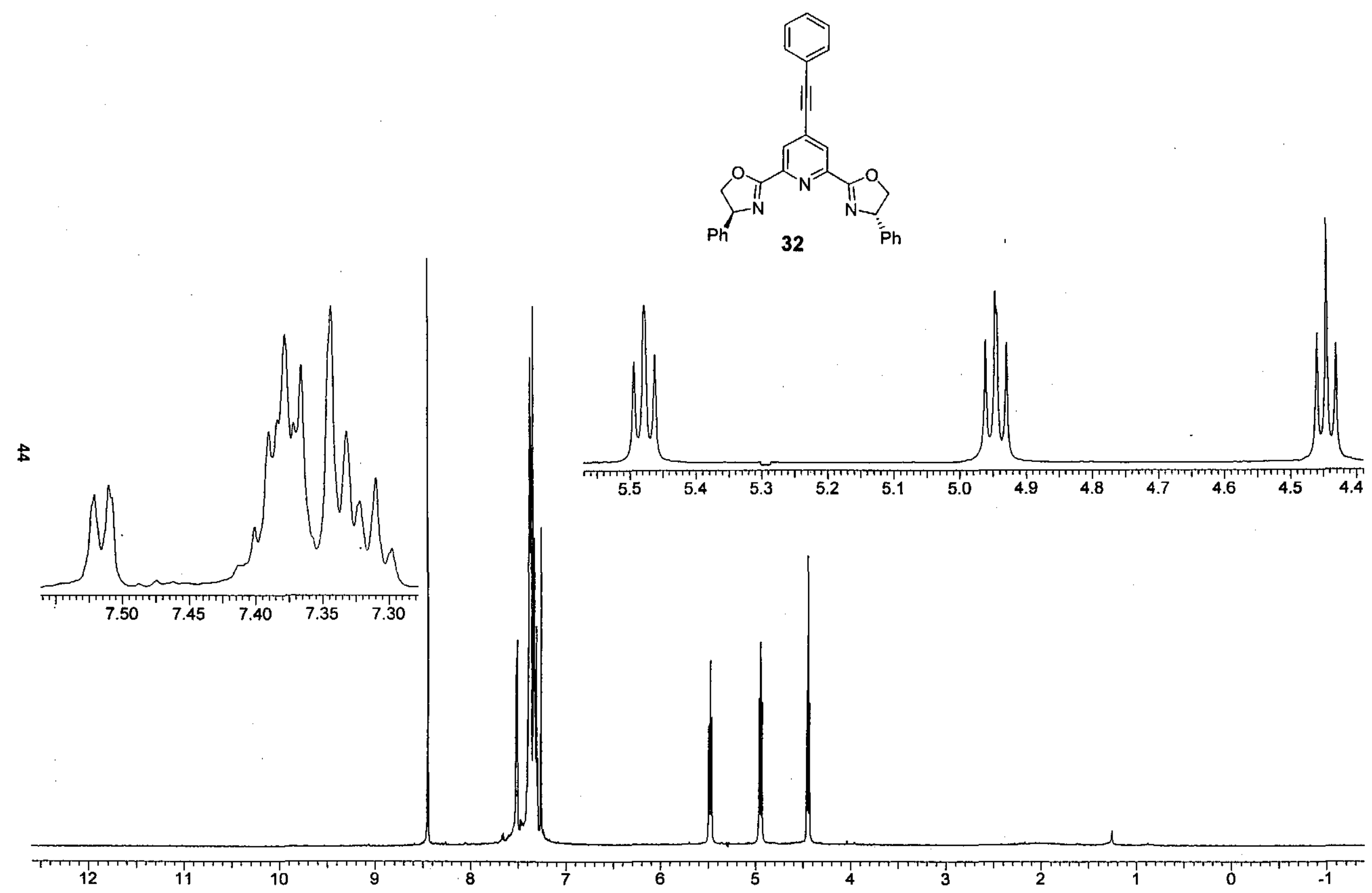




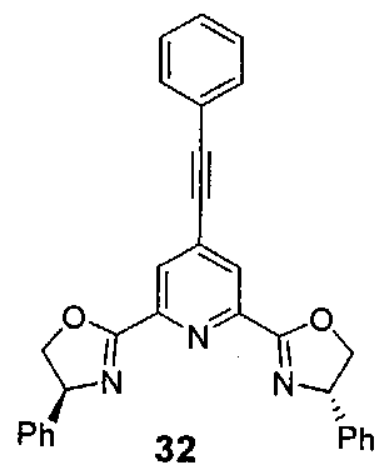

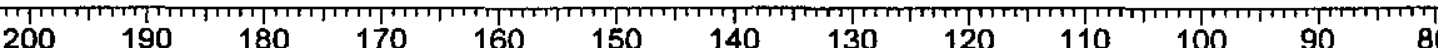

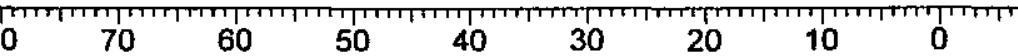

